金印勅書に打ける多數決原理の成立

の爭 者 舉

存 $匚$ 年

在裁住行

を決、訲

認にわ蛅國

め當方公王

はつ机よ和

灰呚來に全

汃皇る 原

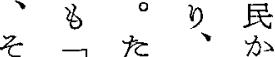

の皇ましら

顏帝市方全

ぶ 潠 ま 学 會

にに一關 致

つ圭九係で

て 亡 公者

はて $の$ 範 枯

明閣三園就

言 與重 がる

を葓 次こ

避る舉第之

湴を諸を

庆侯 機塽建

$\circ$ 會 $內$ 前

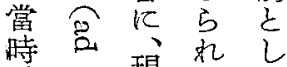

時邑現㹱た

さ总實現 隹

ぎ总搵惯

弆导方票 世

說要 る 諸 紀

が 芯諸当初

行号侯者 め

わ导誰它頃

礼兵誰、加

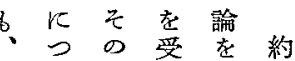

金

右い後け發四

印

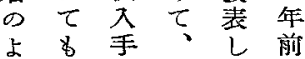

勅

う、し論た $た$

改期得述出筆

副意亩者

をに三党時は

乙 霂の 盡各

之交 乙 般中

をざ獻得 の世

許るをな事

さ之麿加情

れ乙 酳つ加产

た

いが、と萑立

昭号稿を嗝選

和 がの遗や舉

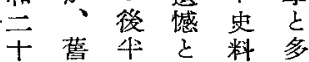

九 稿 $k$ L 0 數

年の若て涉決

七要干w獵原

导旨 修た 立㻎

書

に

打

け

る

て 帝 で 單 ら

た志る同諸

が营が意侯

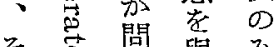

そ官問 與 み

れ灵題究に

を急皇

迅正㛙馀

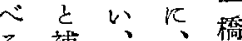

る補こ职碖

と学の聊叢

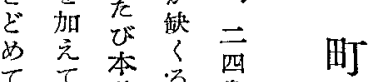

3

數

決

原

理

の

成

IL 


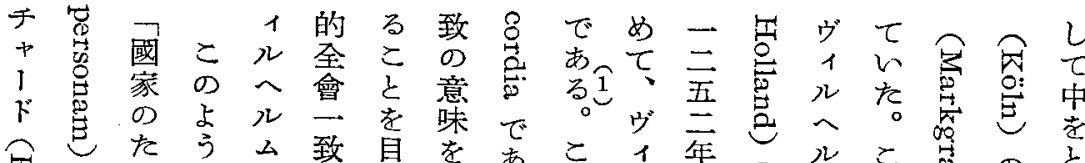

兽之一

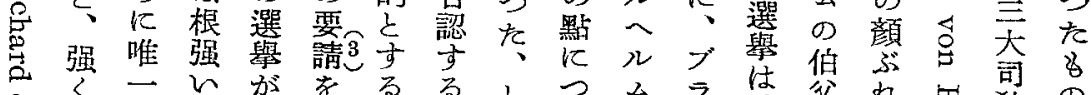

く

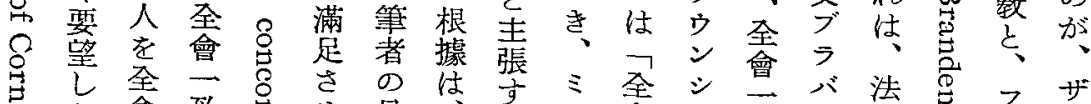

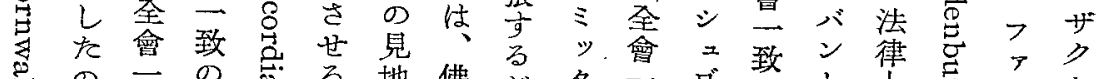

导 の

とあ芯請行

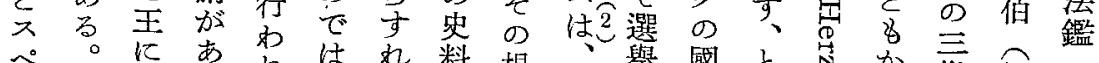

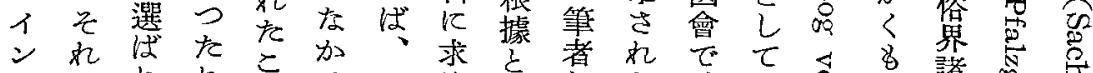

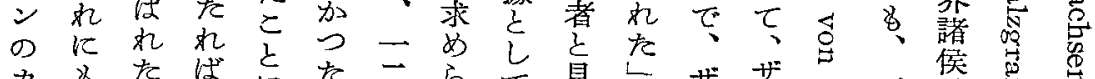

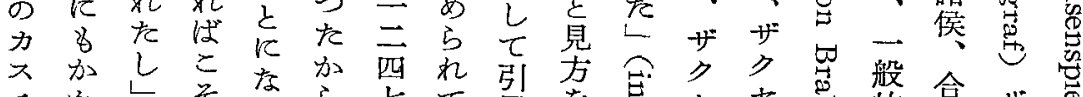

杀出し

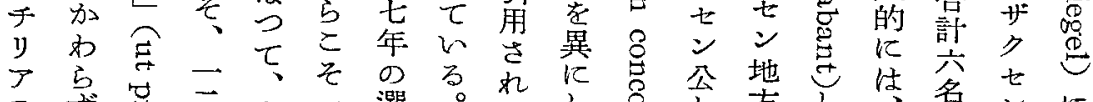

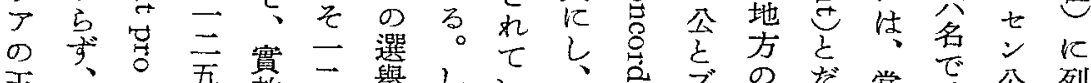

王、五赛 三 舉し

ア 二

$>$ 五 + 新獲年教、史寒离

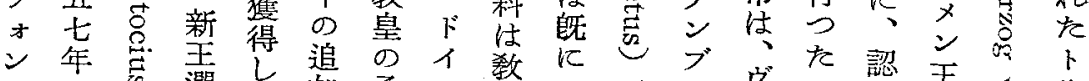

ソ

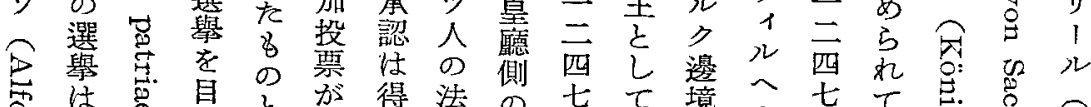

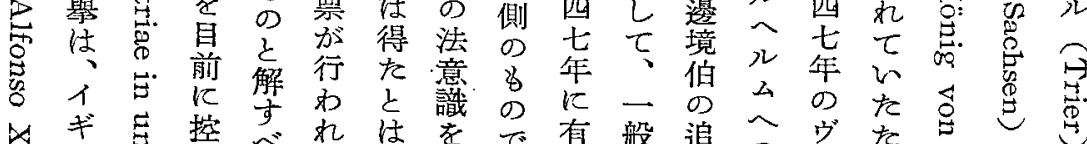

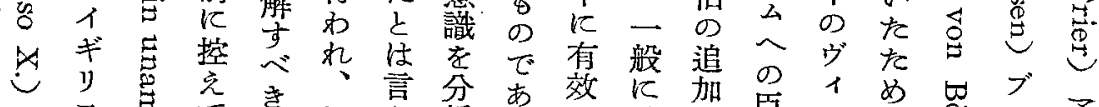

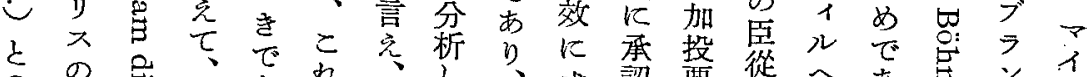

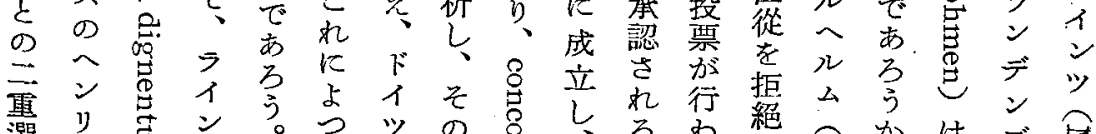

選り

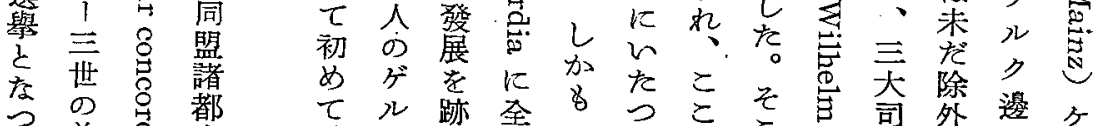

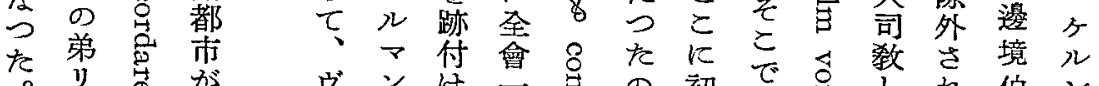

た 
金印勅書における多數決原理の成立

こス 8 官

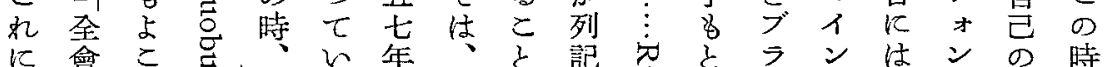

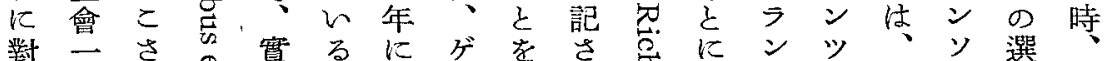

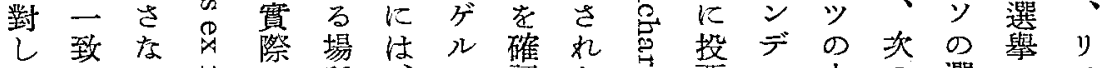

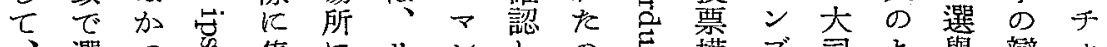

、選つ 子舉た

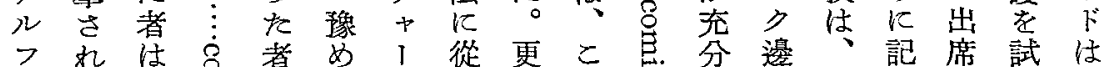

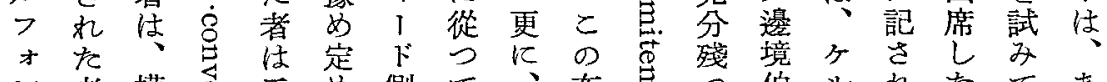

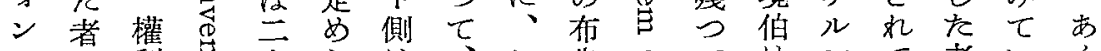
側看を利怘

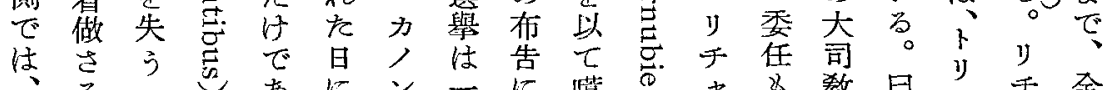

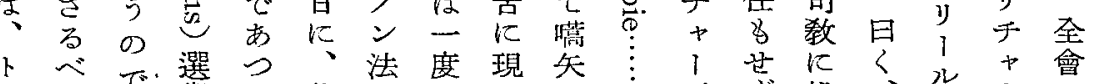

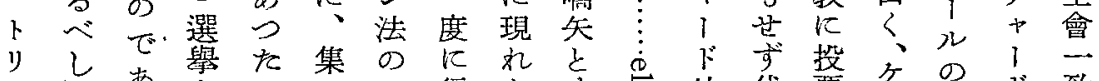

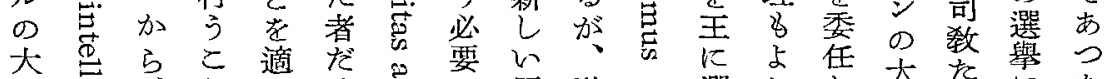

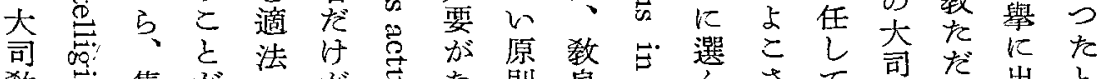

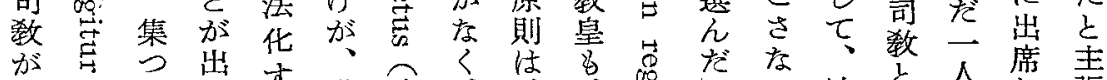

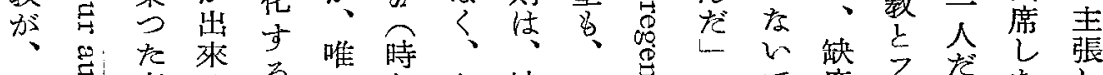

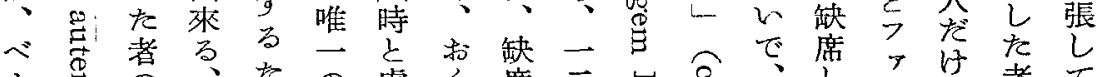

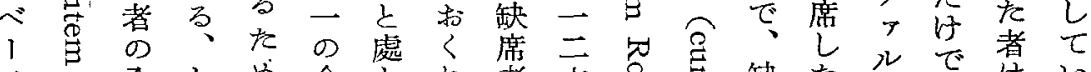

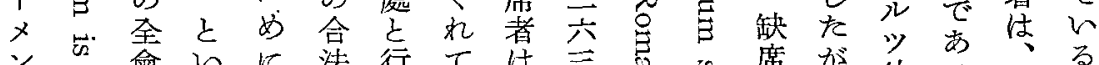

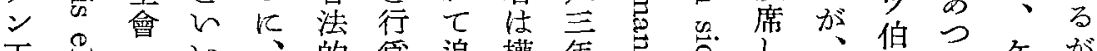

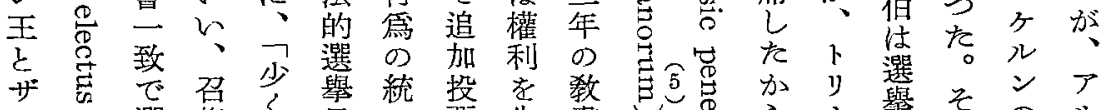

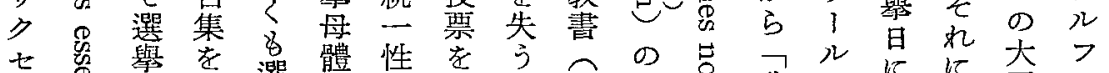

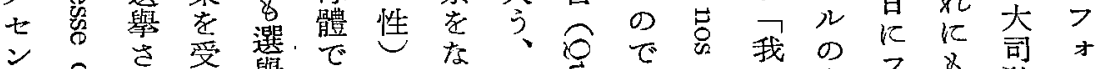

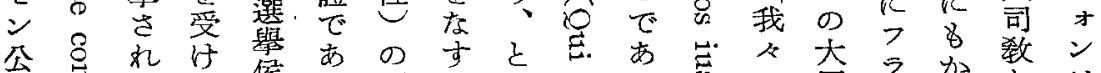
公蒠劣 ブ嵒者に

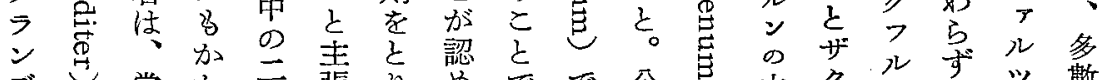

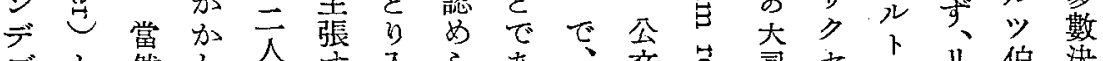
ブ々、然 今

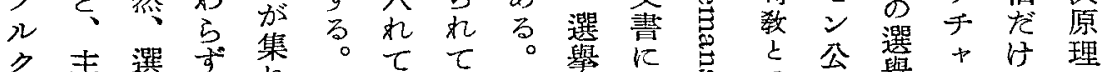

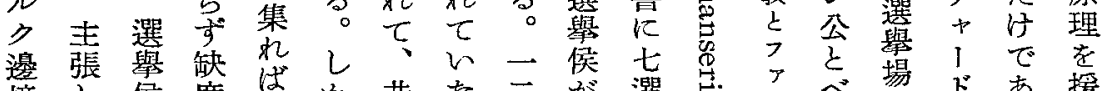
境し 侯 席

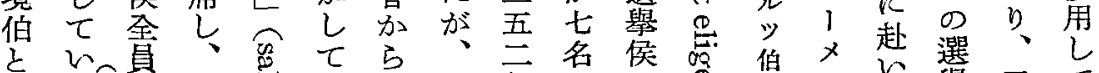

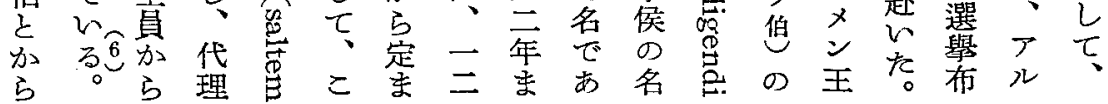




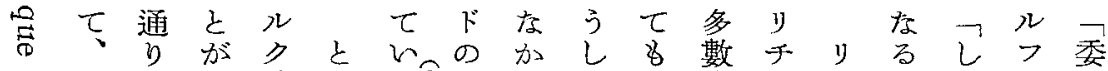
出一一出邊こ后死つた 䓌同人來 境 晋票人がを 二

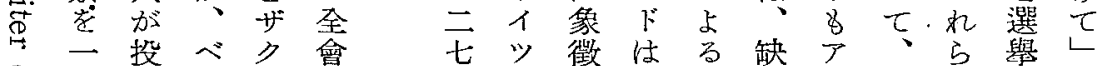

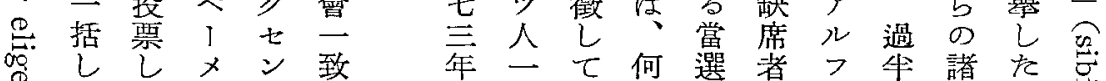

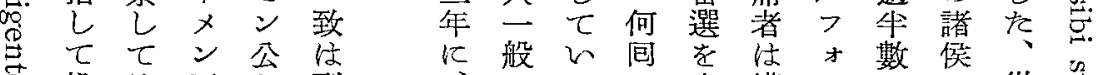

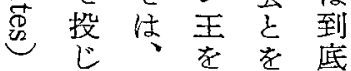
とた不排と瑟 選加致し れ 薄 㦛くへてにだ

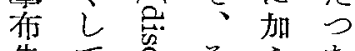

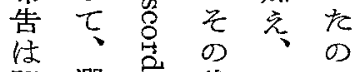
記選 忌代よで 乙侯を江や四 同暴仲く人 る泉は露間 ルの

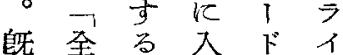
に會恐れルン … 一就たつ選 二致がバ 擧 五它あ 年指を现官住 年指たた 潠しで 公导調 の 加 7 態田務

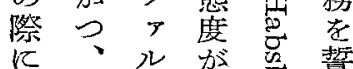

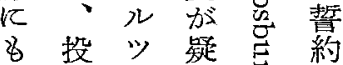

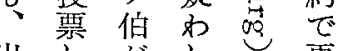
出 ᄂ がしし更 席を、占をに 诸 一全つ候固 がき貝た。補め 缺怘念 席山委こ內 內 者數命任で定 シ

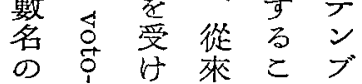




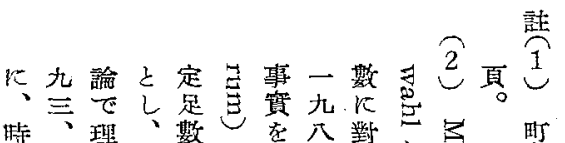

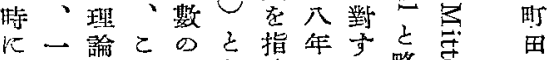
は九付の四な摘以了略蛋了

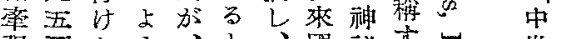

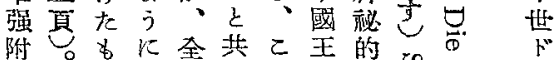

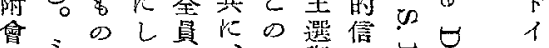

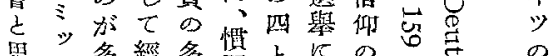

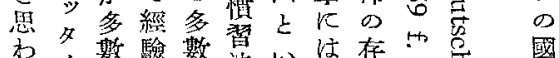

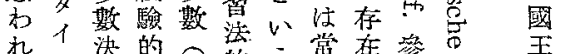

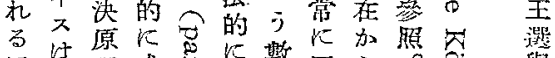

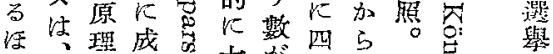

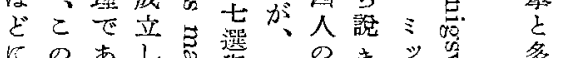

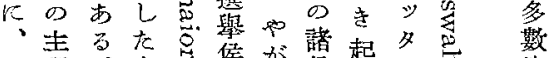

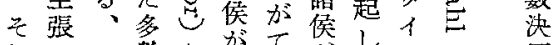

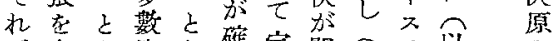

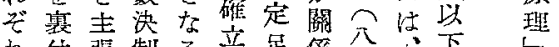

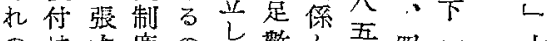

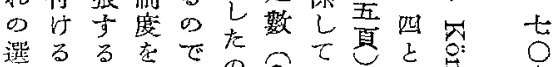

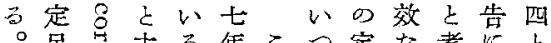
。足吕主了年とつ定な考火上

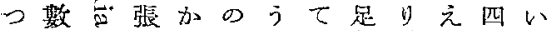
李ををしら選しい数、た名う

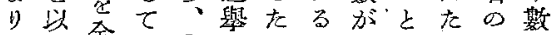
多て余いる b立へ原しめ署で 數適會了点、場二則范で名說 決法致二号三に九でリあし明

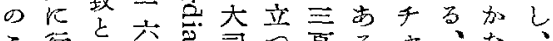

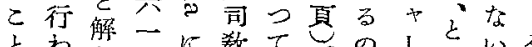

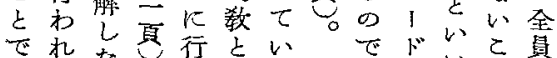

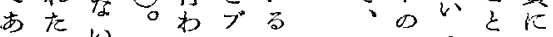

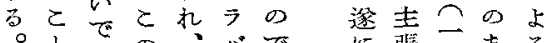
○上小有公で張分古る

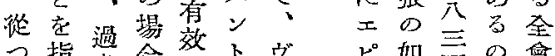

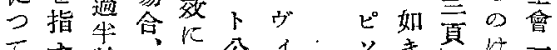

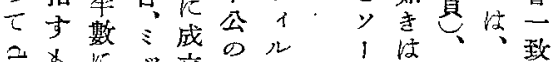

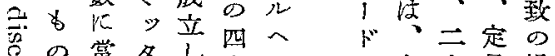

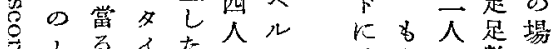
之る る 考不選のつ当出园

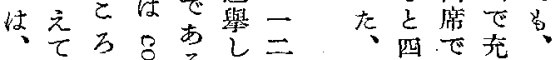
多以の总当元四上人有分布
て 力果光尖总公委

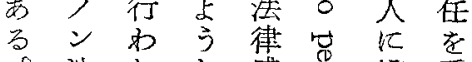

法和上感惫投受

へたし情志票所

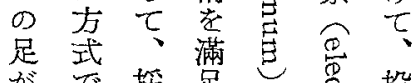

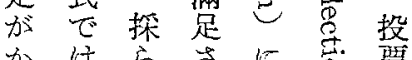

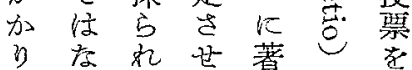

をいたるしを行

作で步をく委り

る $あ め$ 似任て

をるでにてては

選引あいてい

舉。つ實るいる

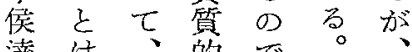

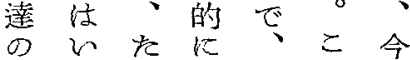

法充ま注力口度

律、た全，點吉

觀こ省の會法扢選

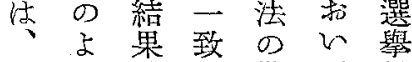

$\Rightarrow j$ 的古繼て 侯

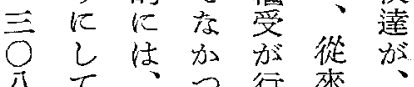

八七行來、

年、カた支自

のら゙, \&如方身

選ルンのた式ま

舉 マ 法に の

にン的、ではは

括法亡恰 あ異代

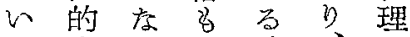

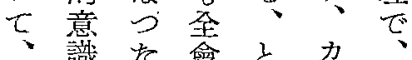

更に㤎一說, 全

比立、致く京

一衣决で者法出

段店しあ当の席

とがてつあ

- 5 力

力、ノ加新人拉

>形ンの、にき

ン式法よ實よな

法的的引度るが

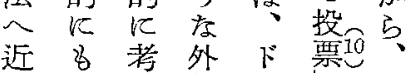

近8 考外 ド票仰

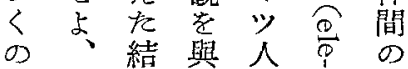




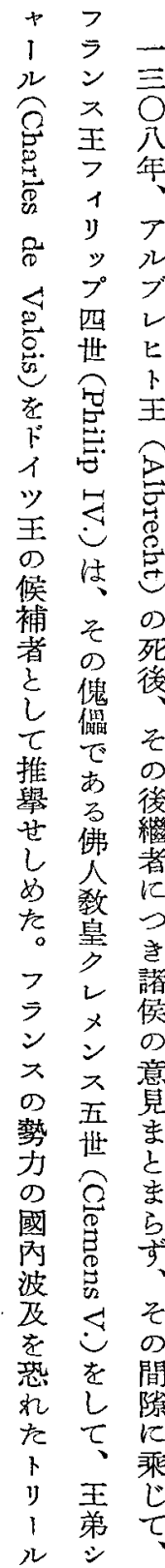

3す题成書ルわ會つあでに五吕ラで數

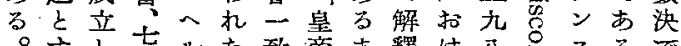

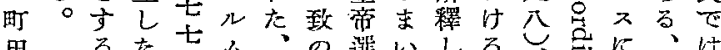
田るた真么の選いしるY气に、は

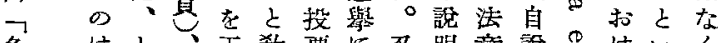

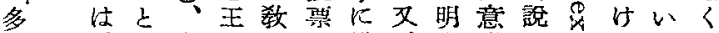

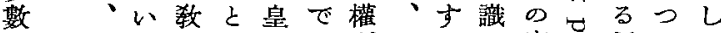

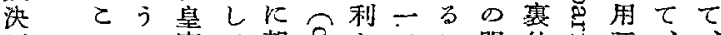

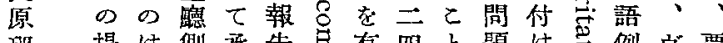
理場は側承告貝有四々題け产例占票 の合賞の認し导士七のをを施 展、然人乚、晋了年賞、儿⿺

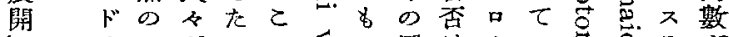

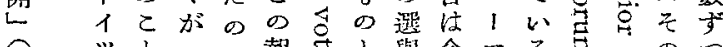

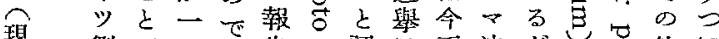

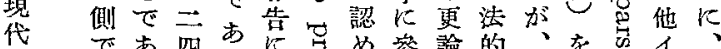

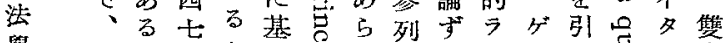

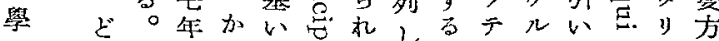

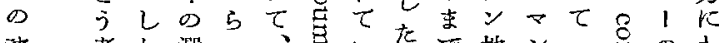

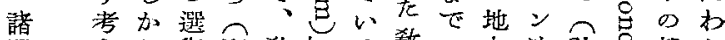

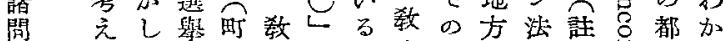

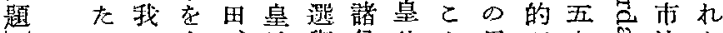

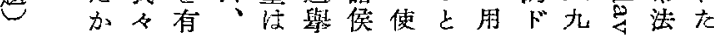
二、が效前ヴがめ節で語 1 六导や場

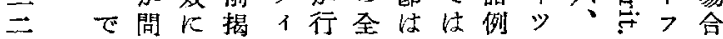

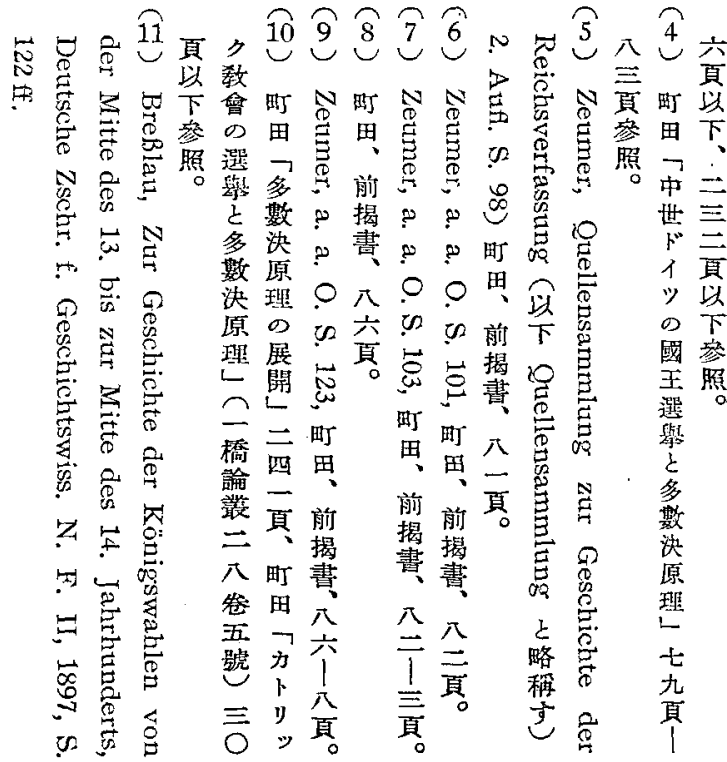


金印勅書に和讨る多數決原理の成立

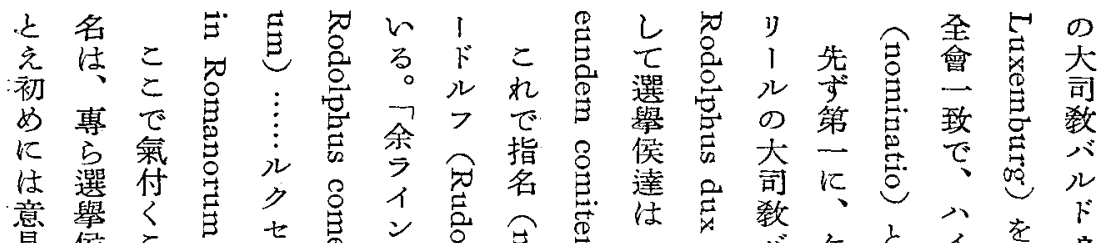

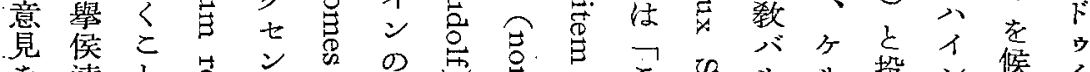

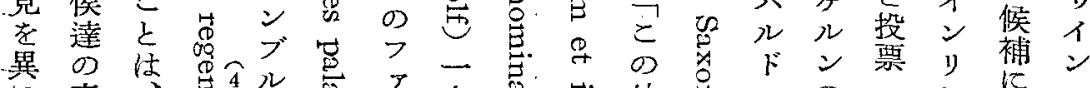

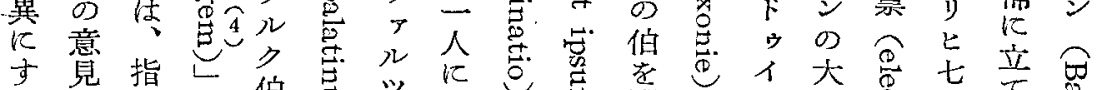

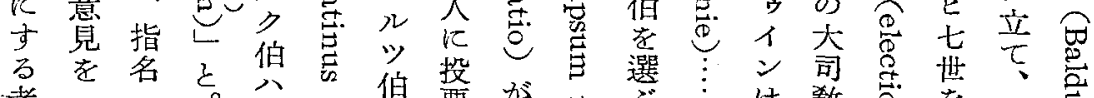

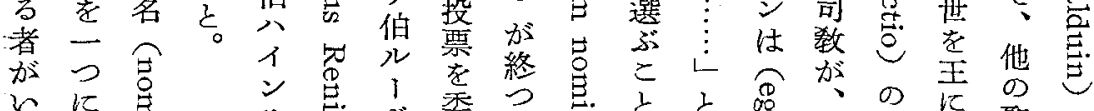
几に主 y

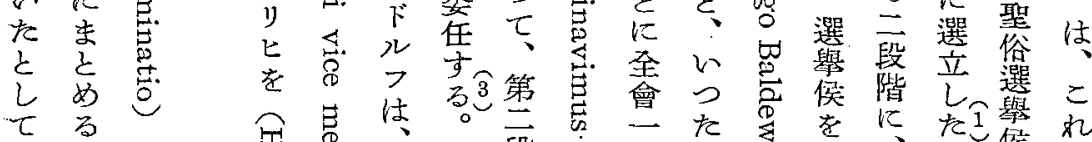
8 こ

$こ と$ 筫 和空 極怘 法 力 $\overrightarrow{0}$ 說 變 得 3

ᄂ 䆑了

宁市

多吉古

क

省㤩な゙

意导 る

k 省

同 二

調重

巳 點 三

サが年

る置の

がか 選

、れ舉

最て

後いで

まては

馀た指

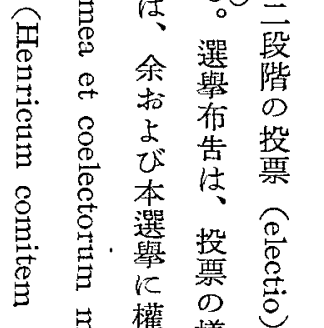

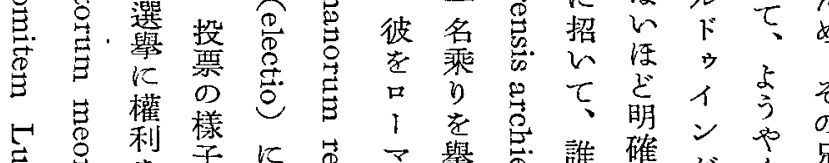

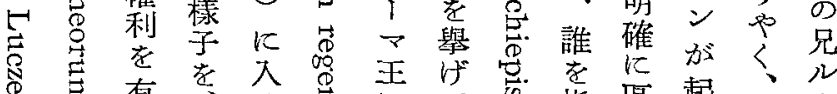

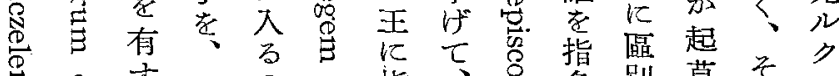

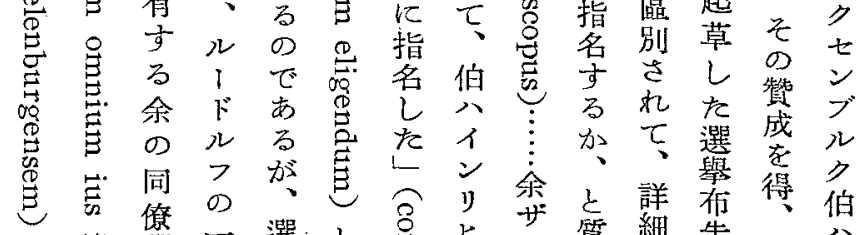

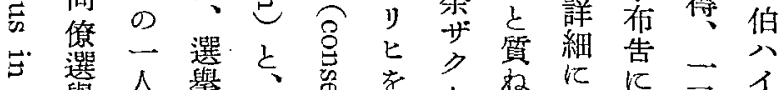

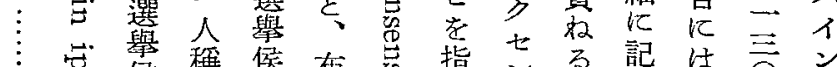




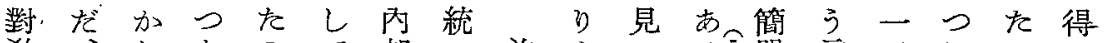

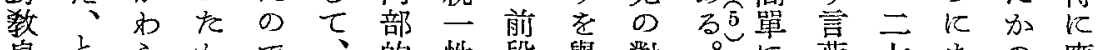

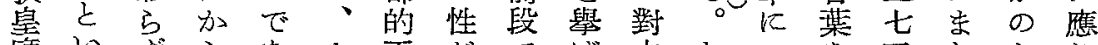

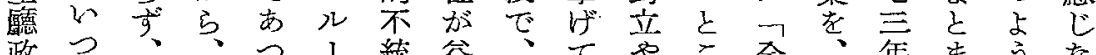

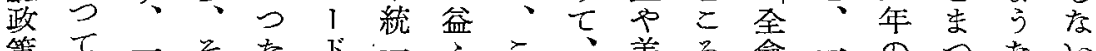

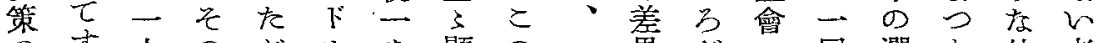
のす人のがルを顯の一異が同選を外者 そまに上、フ㳩著よ同を、致汃藇汃觀各

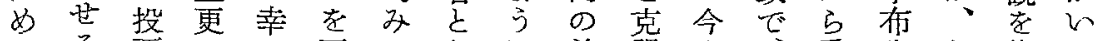
にる票にに王になに前菔や委告と作た

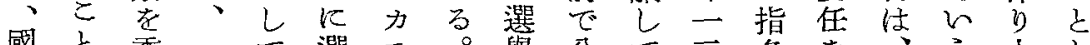
國占委

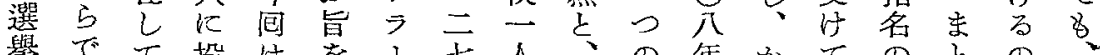

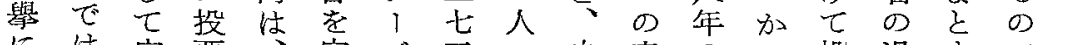
には宣瞢、宣ジ三一自意のつ投過恋で少 市言を意言二年人㞯見選、整程るある

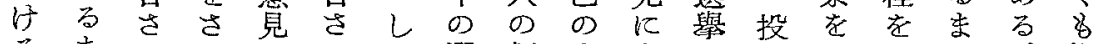

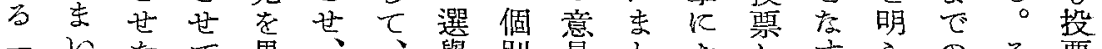

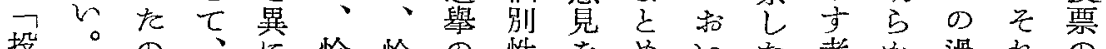
投起の、に恰恰の性をめいた者方過扎の

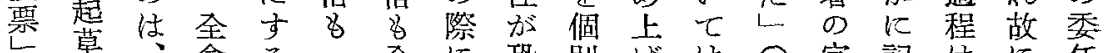

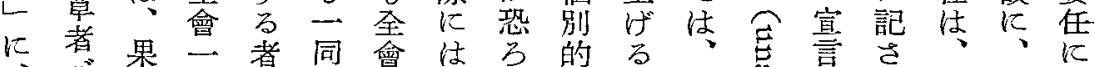

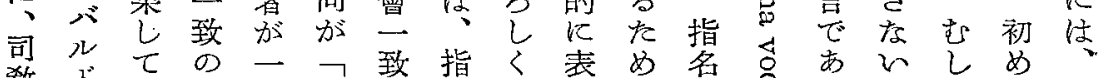

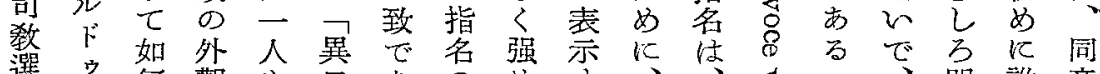
箕

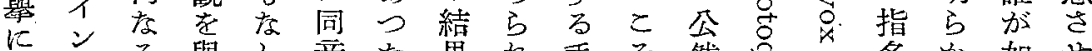
技る與し音を果机手て然芑名加世

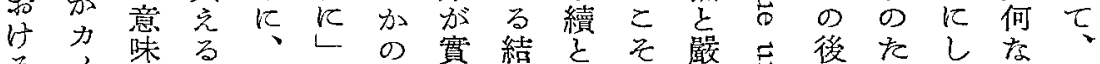

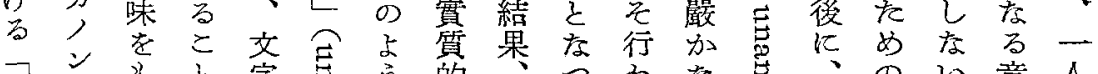

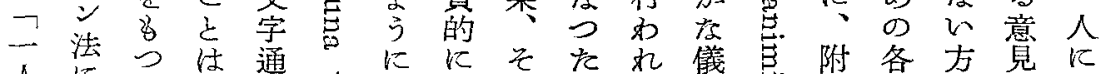

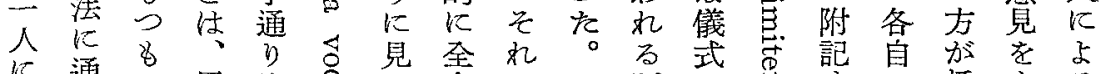

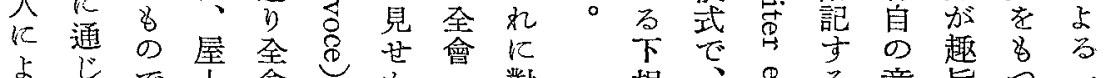

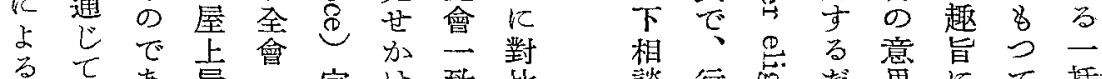

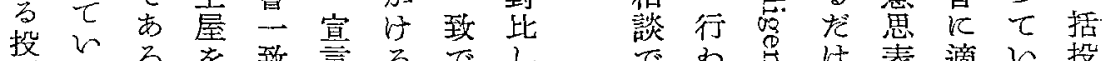
票たるを致言るでしでわ哭り表適い投

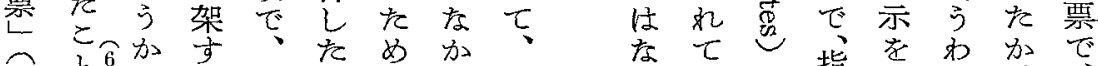

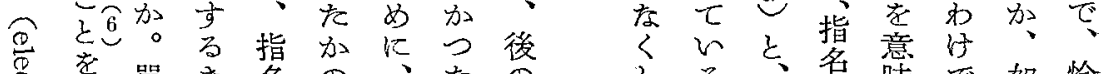

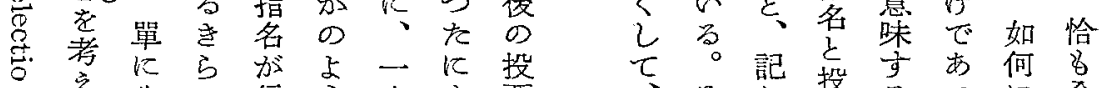

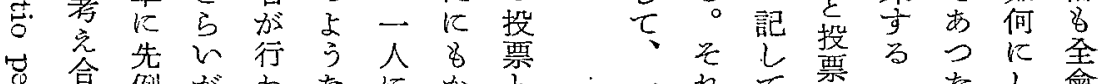

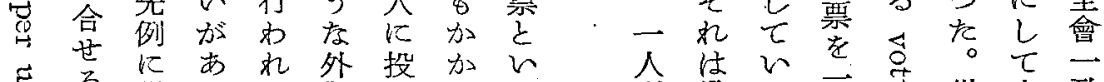

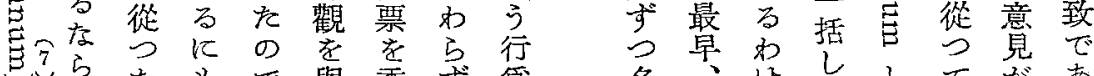

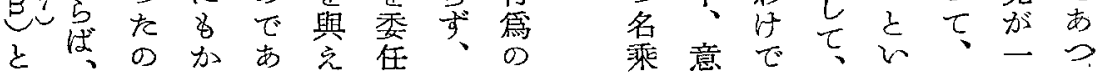




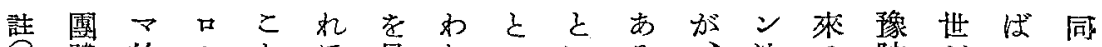

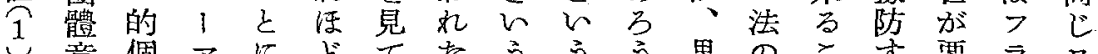

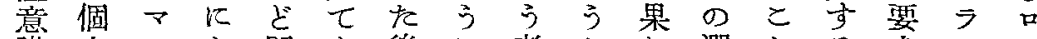

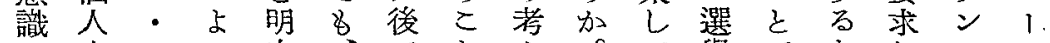

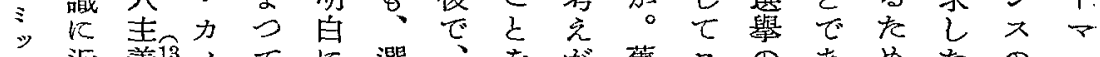

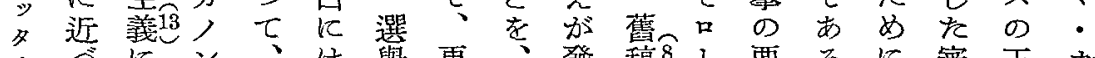

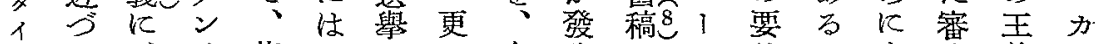

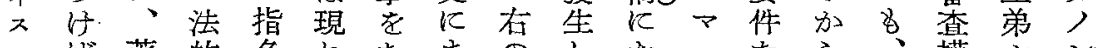

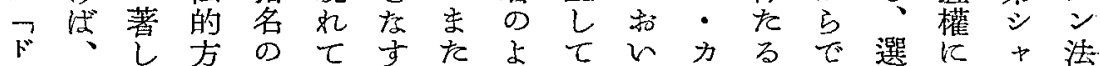
1 口 法、坻を接 探 吏

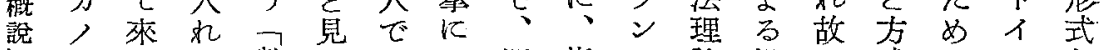

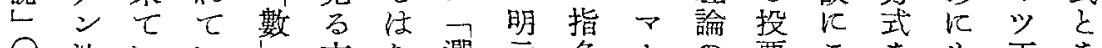

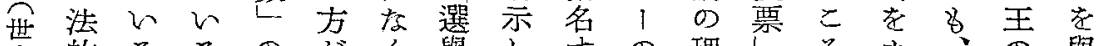
良的る る

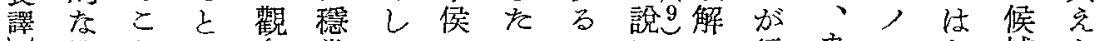

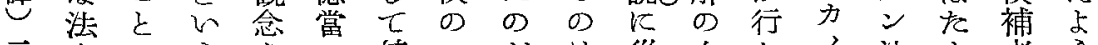

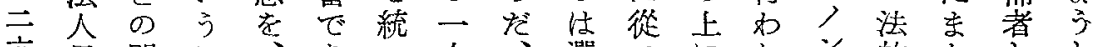

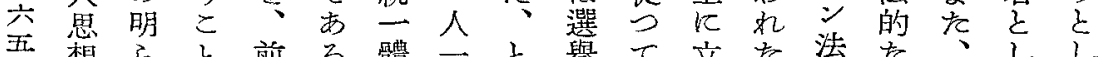

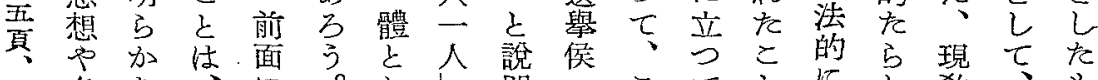

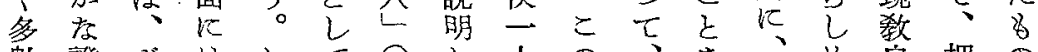

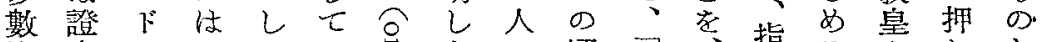
決左

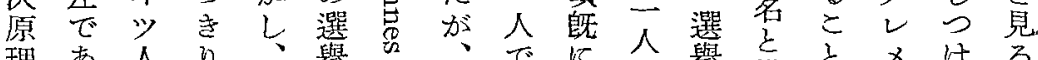

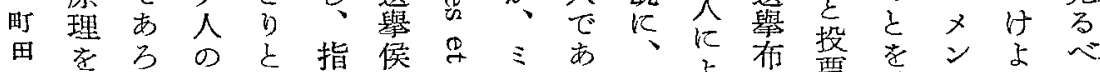

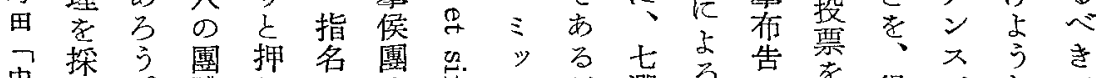

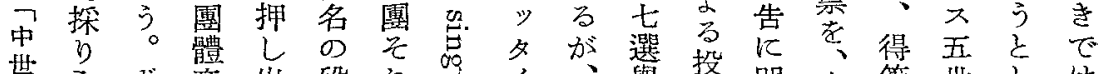
世”

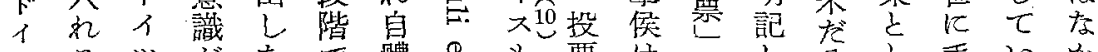

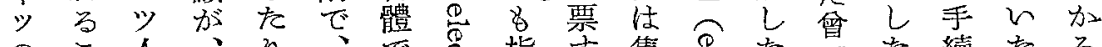

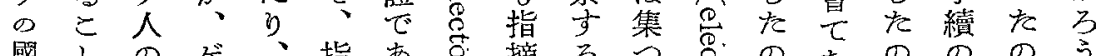

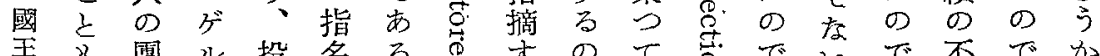

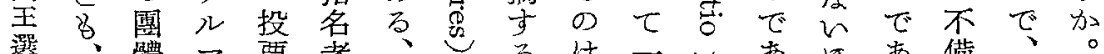
藇や體マ

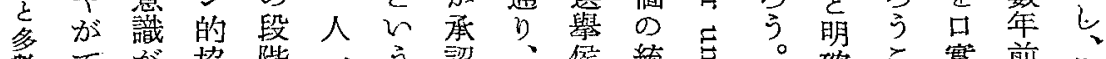

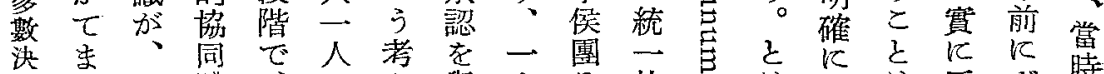

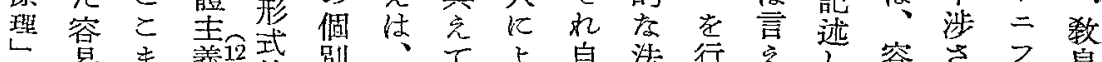

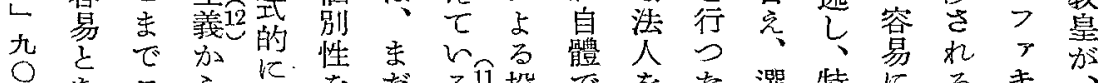

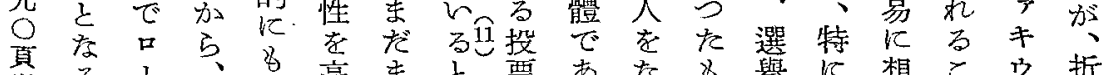

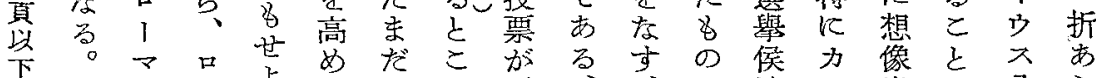

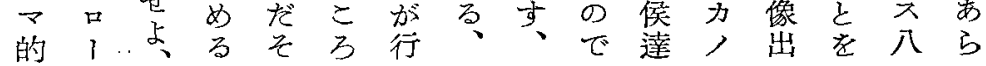




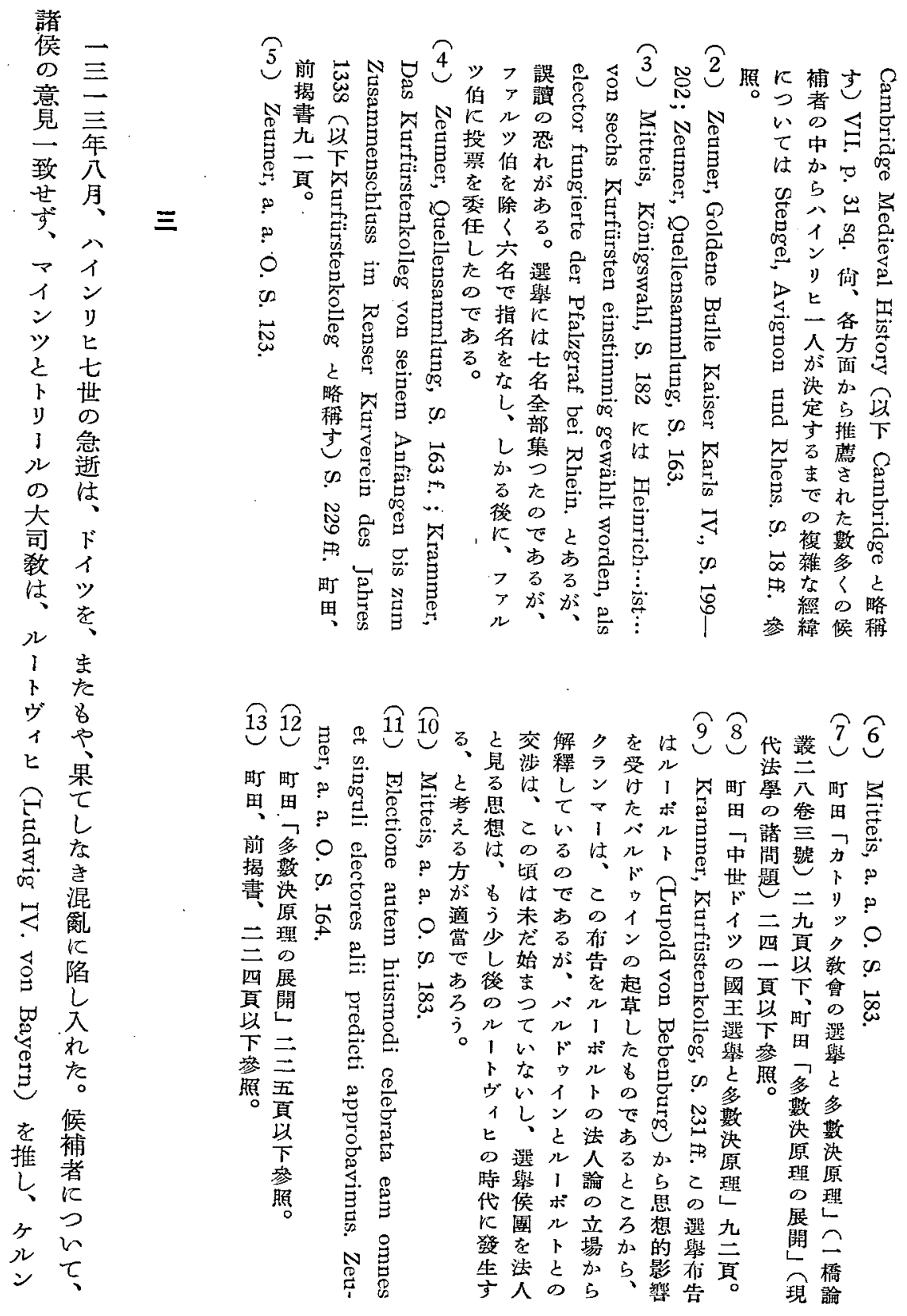




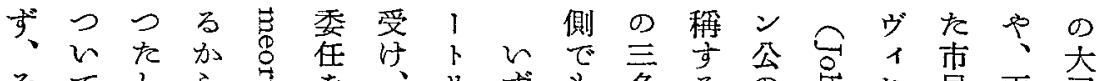

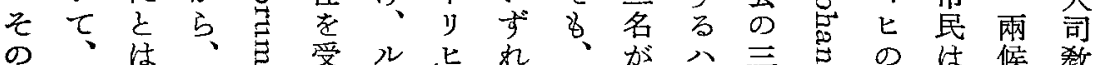

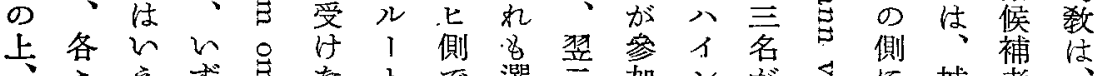

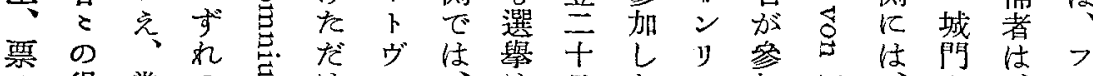

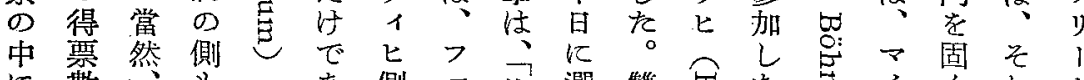

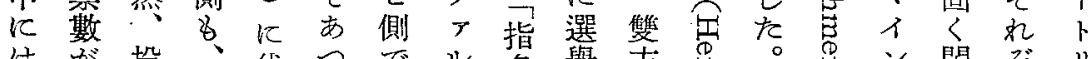

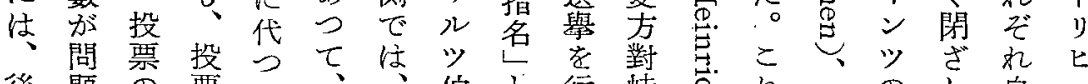
後題 票

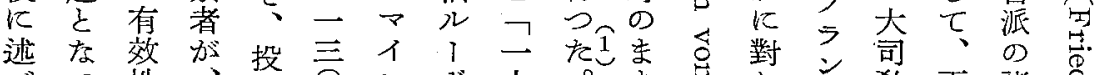
心性、摽

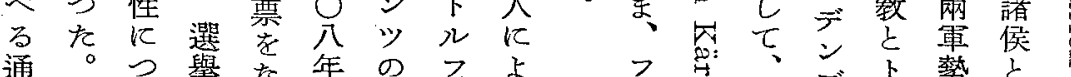

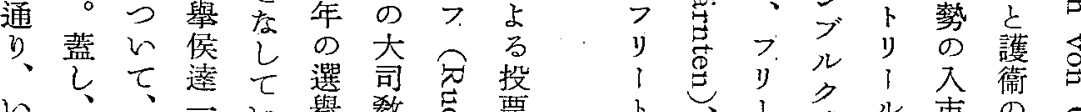

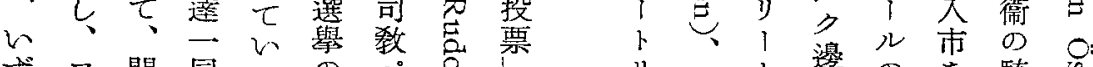
ずフ 開 同 る

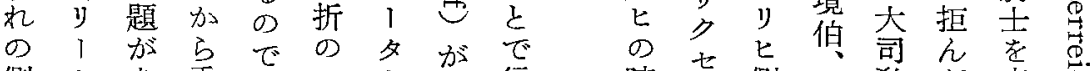

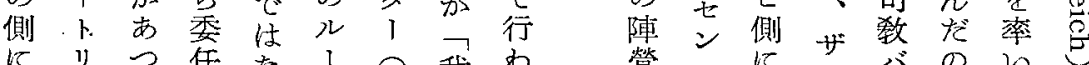

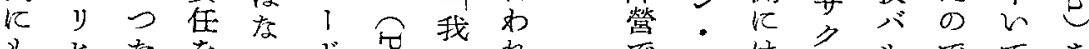

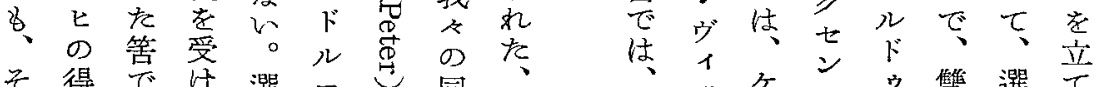

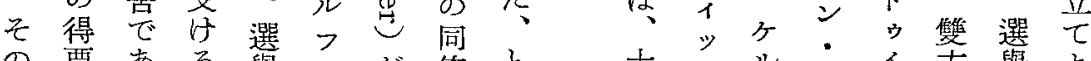

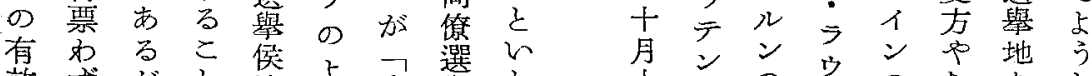

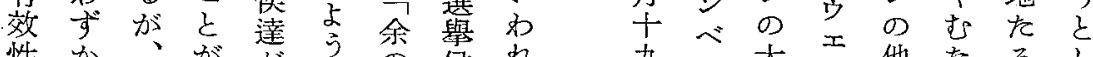

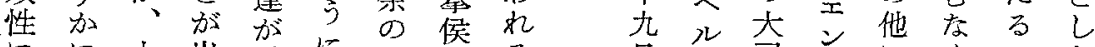
《に大出、に同達る

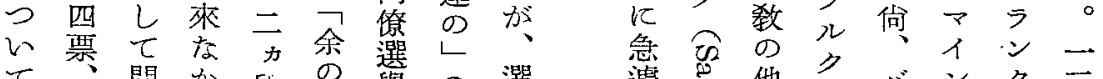

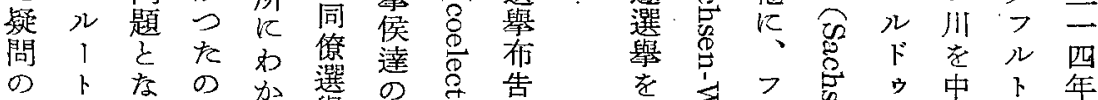

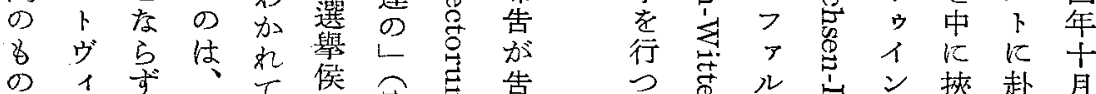

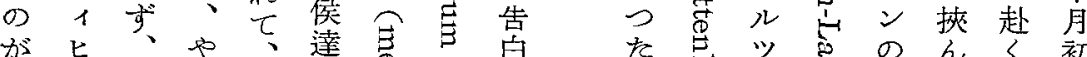

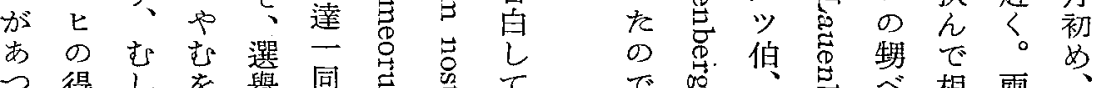

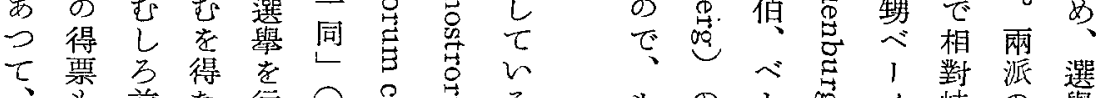

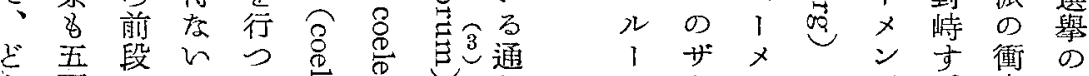

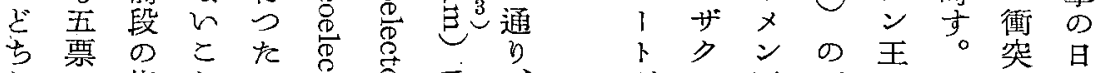

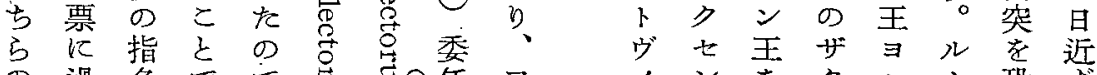

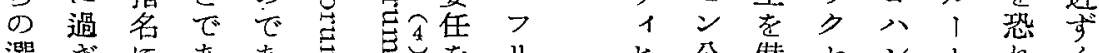
選ざにああ志导をり

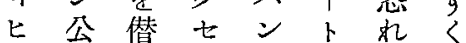


來

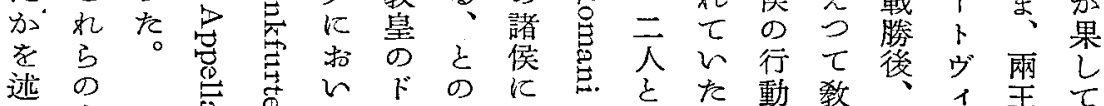

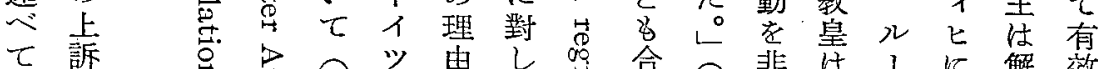

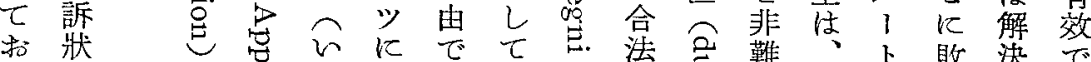

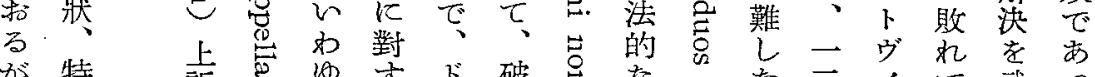

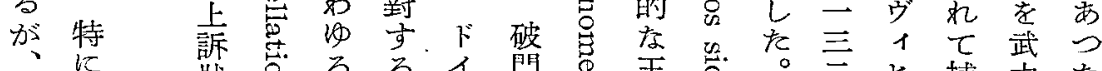

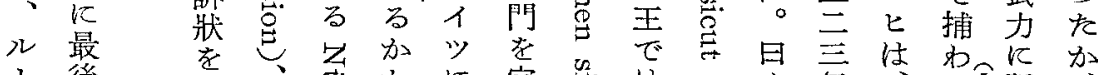

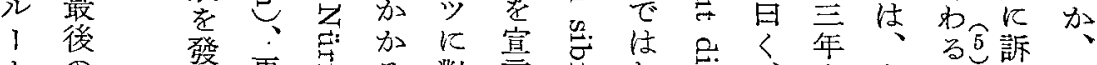

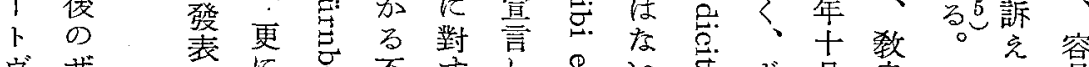

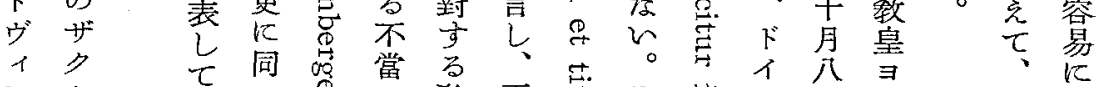

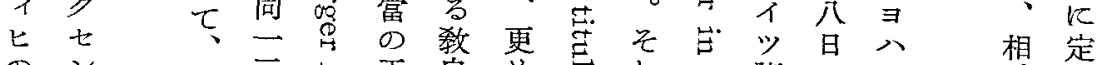

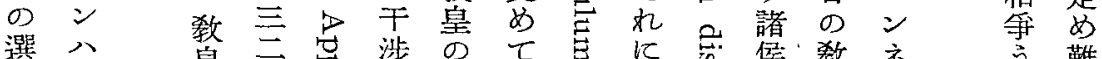

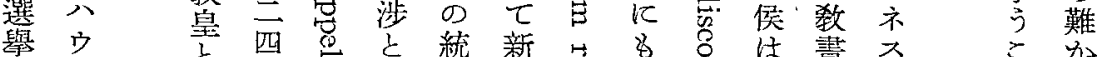

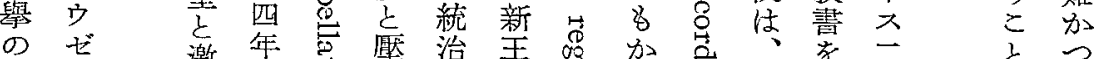

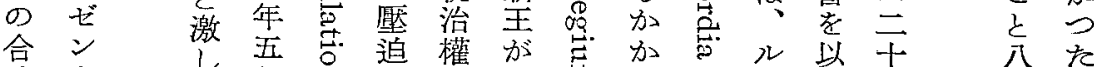

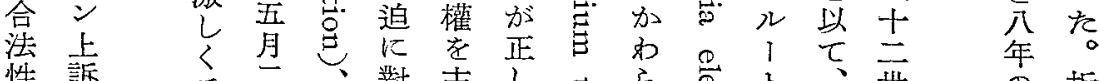

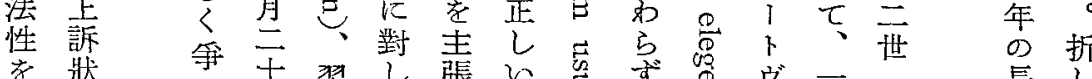

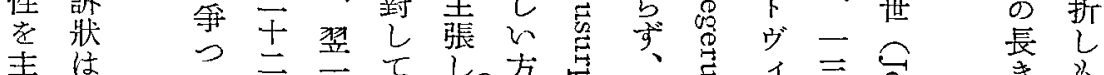

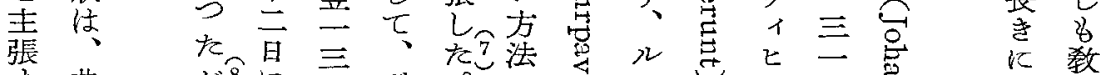

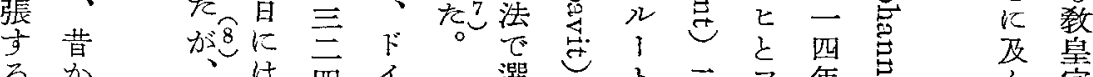

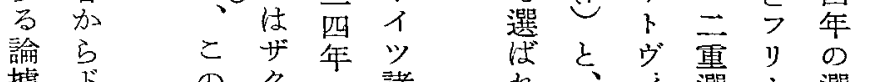

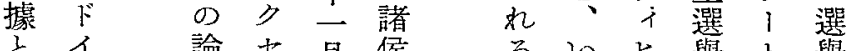

そイ 論せ月侯

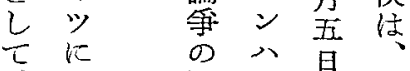
技間品先

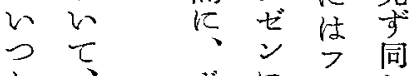

L k k 5 .

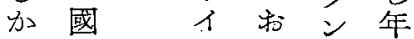

口王

I選人 $\tau>+$

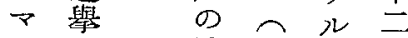

· 怔法い下尚

カぞ 律务に十

, の 觀的招公

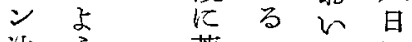

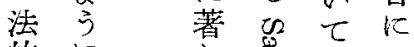

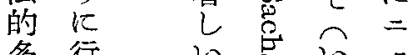

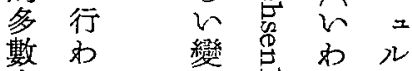

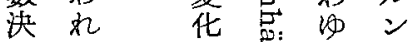

原七驾苦当心

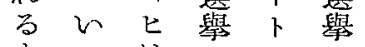

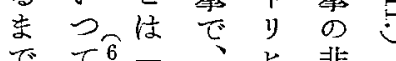

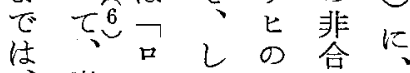

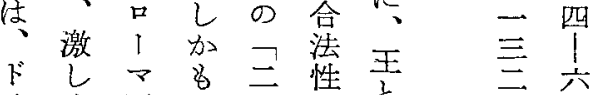

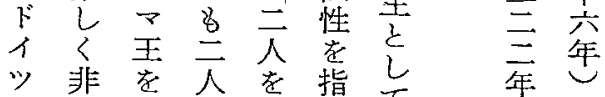

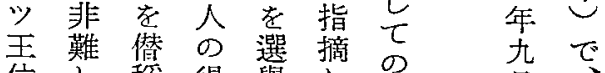

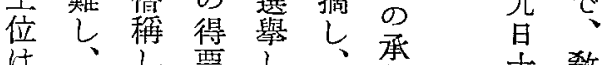

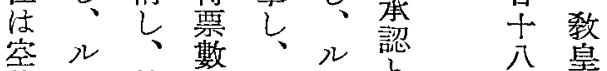

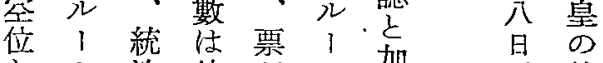

之沿伯覀卜嶎、仲

看占權蚛公占冠>裁

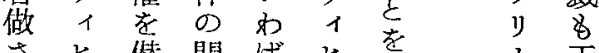

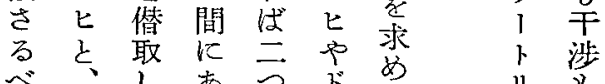

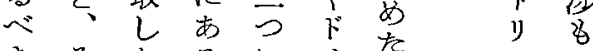

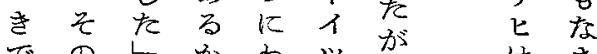

はき 


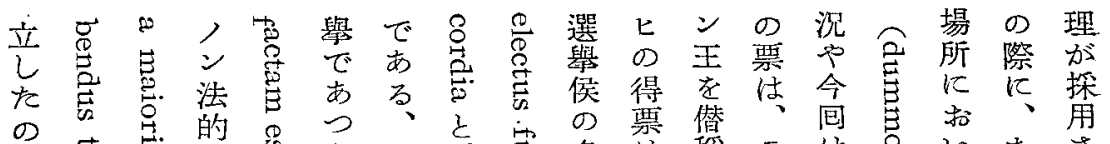

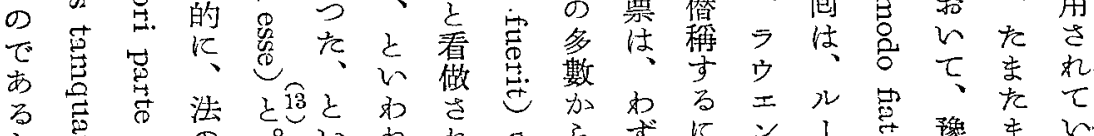

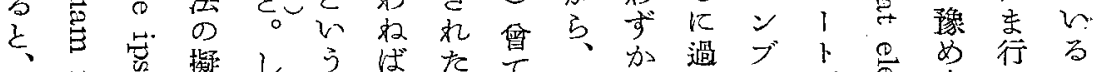

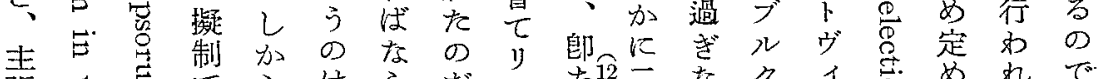

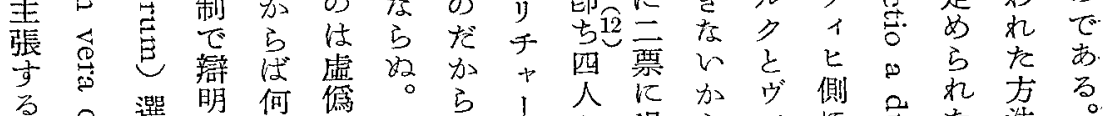

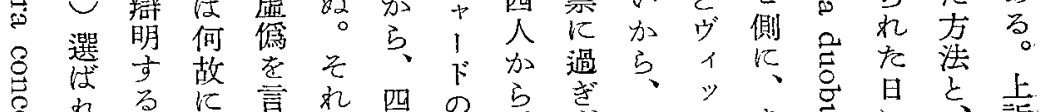

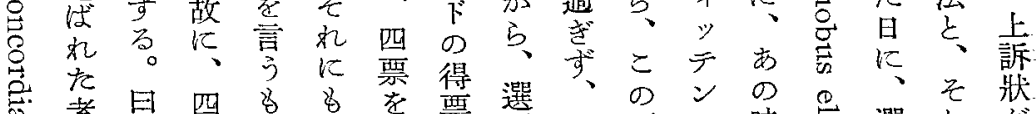

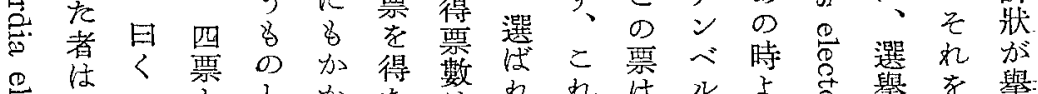

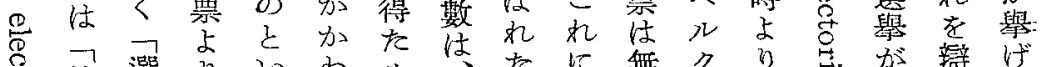

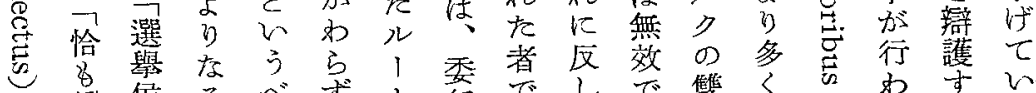

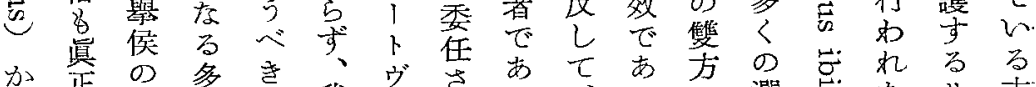

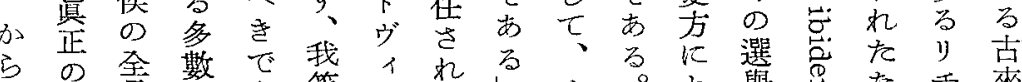

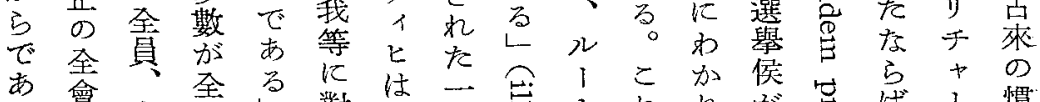
あ 會 る 全 る

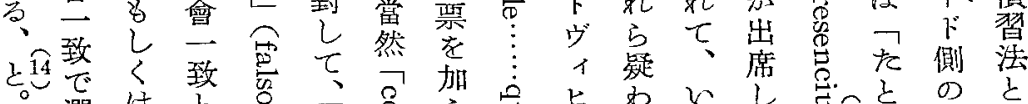

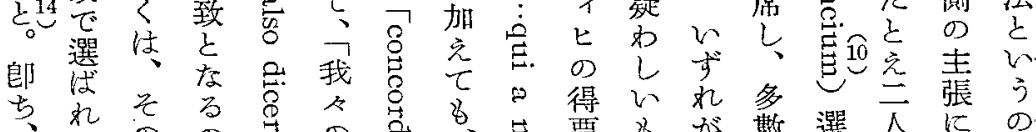

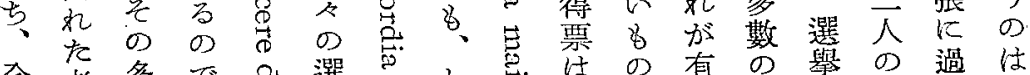

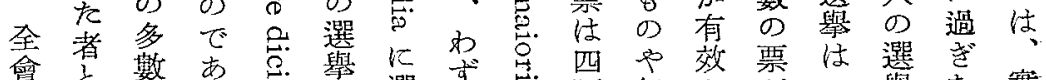

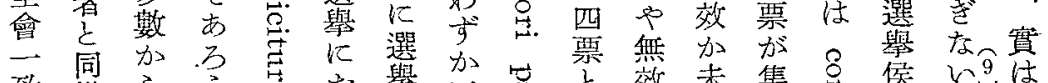

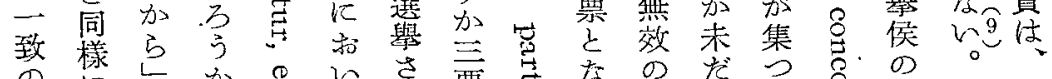

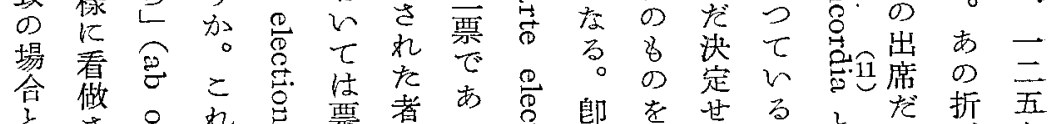
之娄机兽票者 同裙点

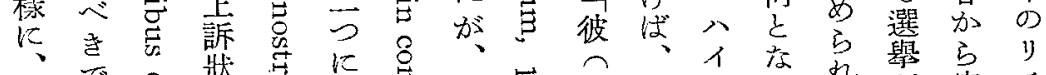
選 あ゙

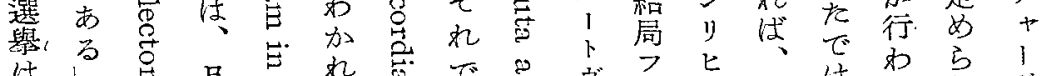

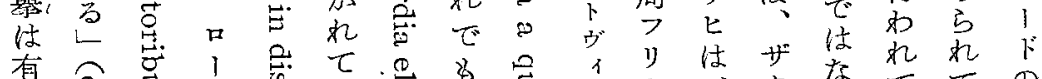

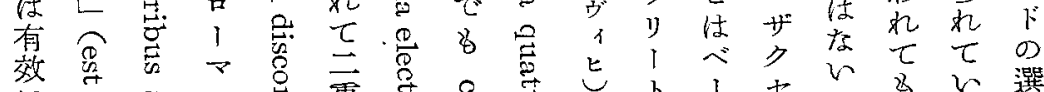

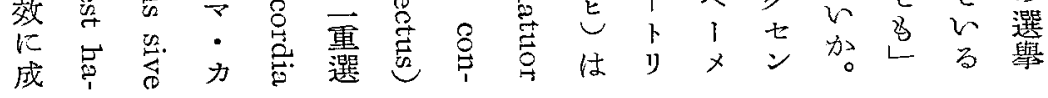




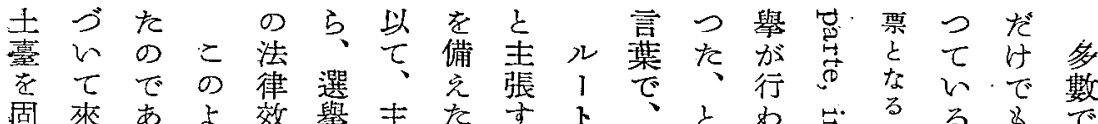

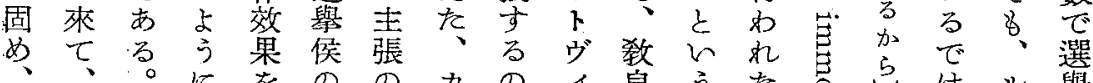

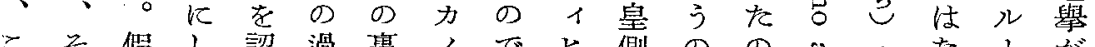

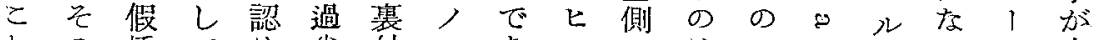

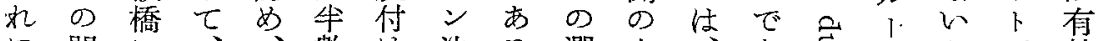

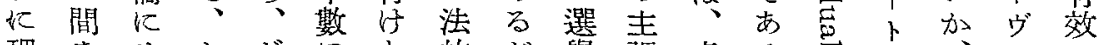

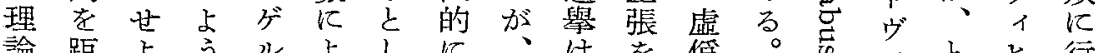

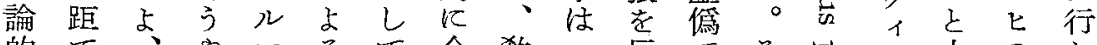

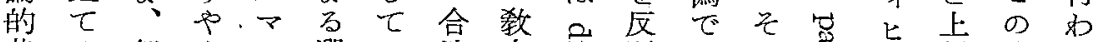

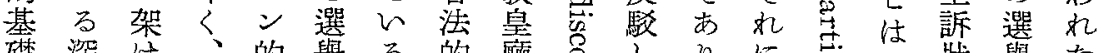

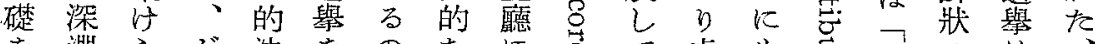

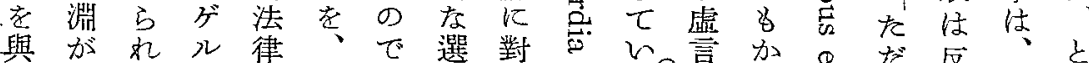

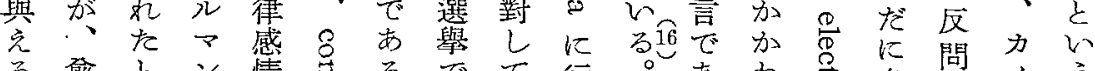

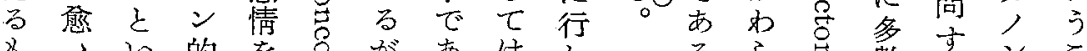

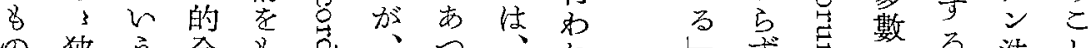

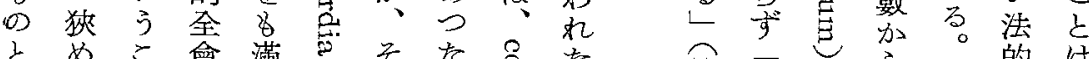

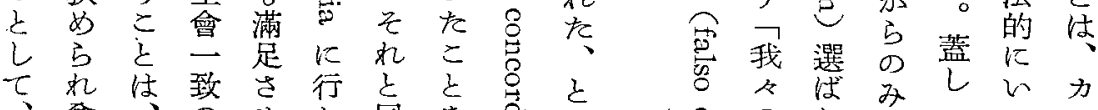

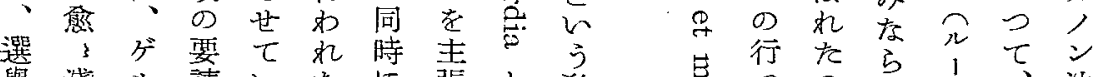
舉淺ル淸いた張と敉

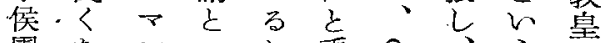
團なン口わ看 $8 、 3$ 側 のつ的 I $\forall$ 做㝵更言

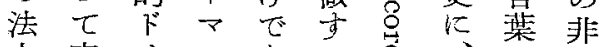

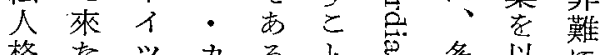

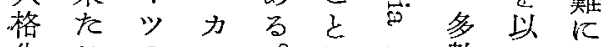
化この, をと團之主洪、主 見妾體法接規当 逃物意的文本殊定 反 高語 識多、來に通駁

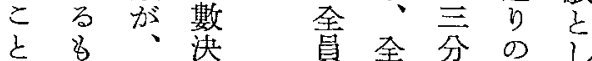

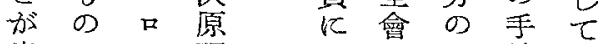
出で।理文百續、

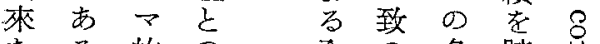
死的 $の$ 全 $の$ 多踏导 品個間會意數坊导 で、人に是昧洪、蒿

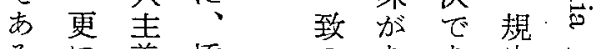

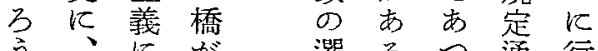
引、以茷選るつ通行

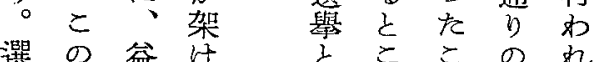

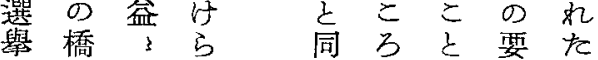
侯 0 近れ 芯行

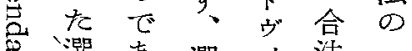
璦擧 る

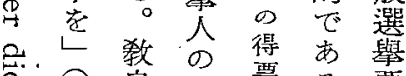

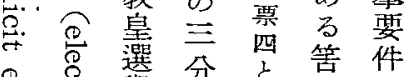

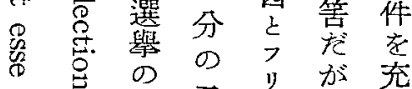

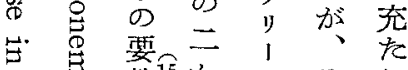

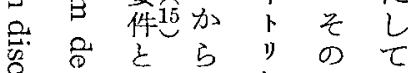
号号同 さ

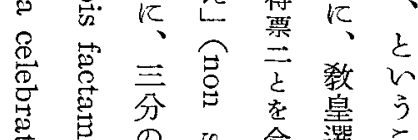

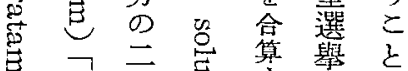

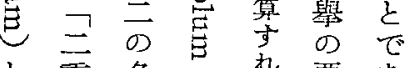
之重多の机要あ 激舉洪点全 件 る しでで导部を゙ そ 心あ準息六適れ 


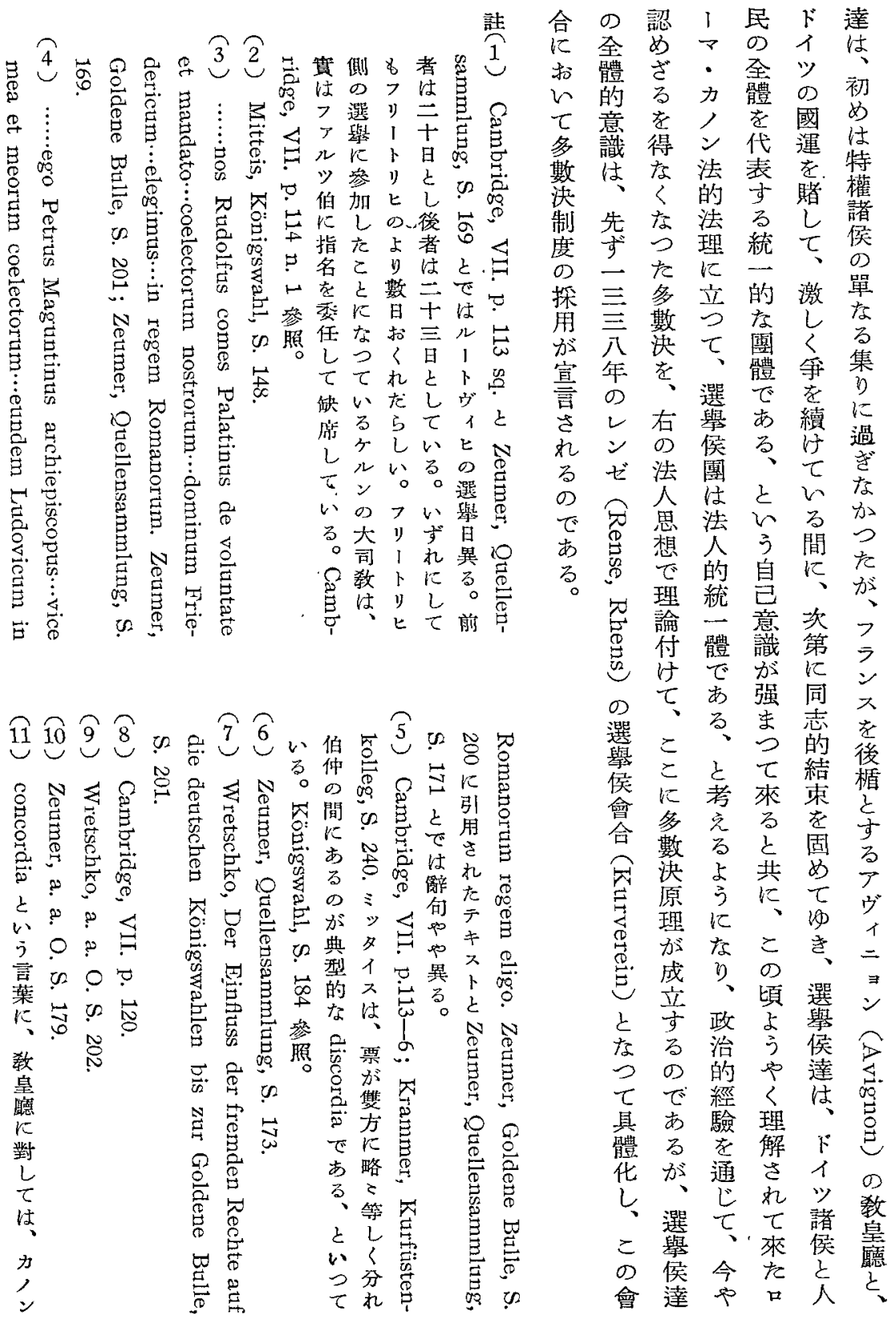



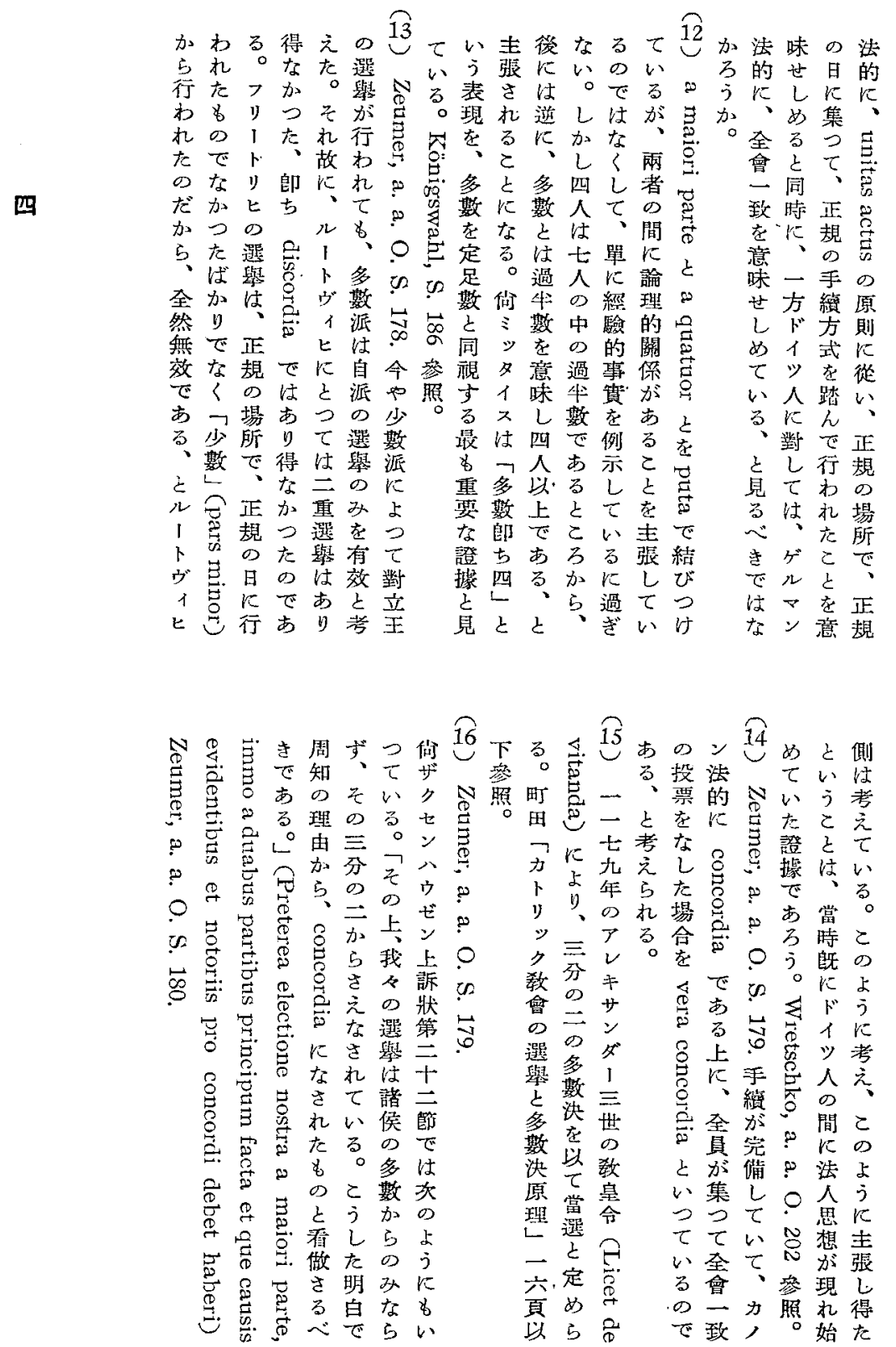


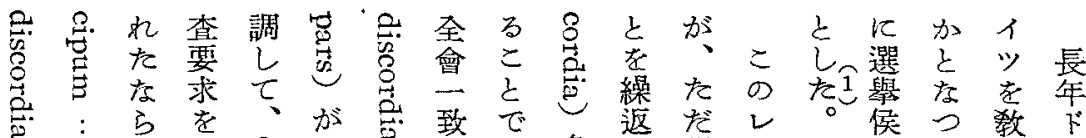

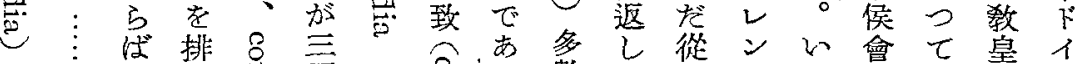

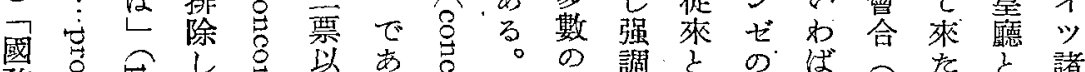

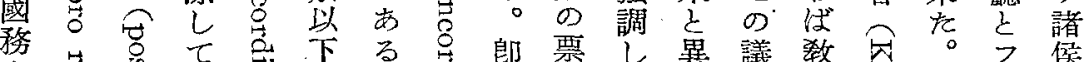
南员七

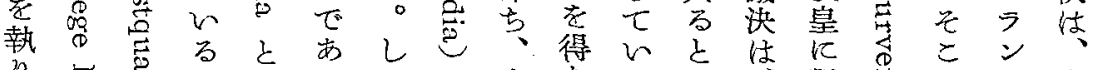

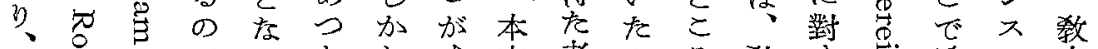

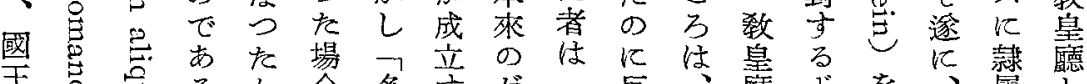

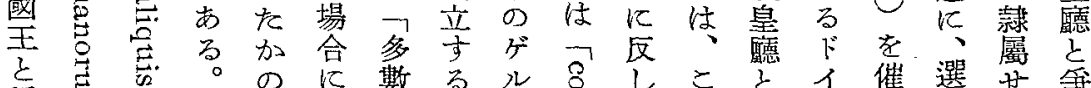
㛵

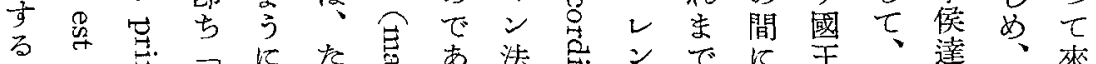
に

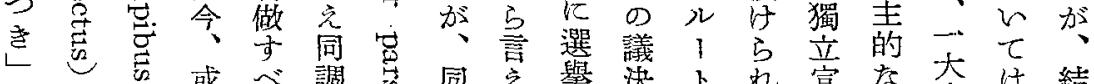

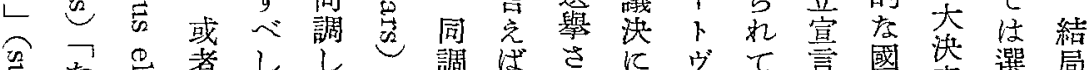

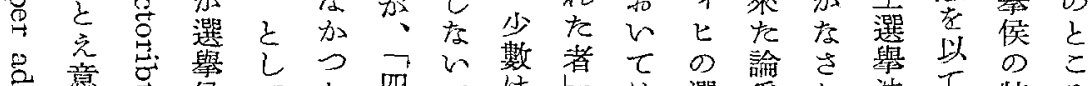

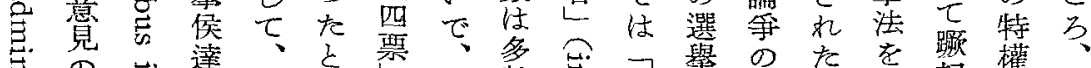

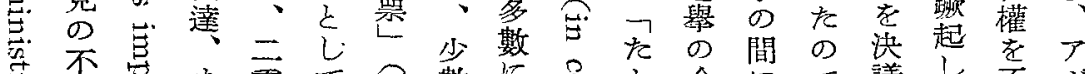
节不总

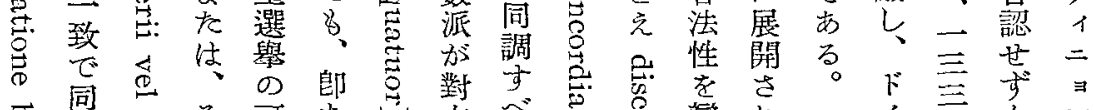

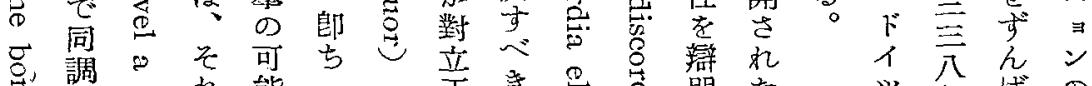

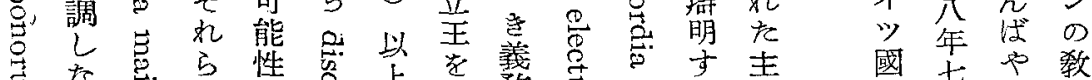
壱总

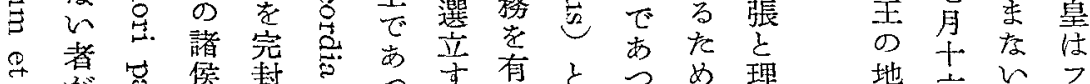

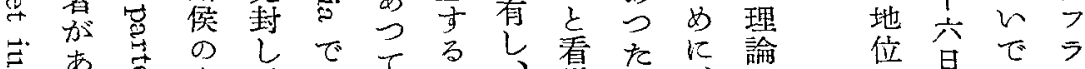

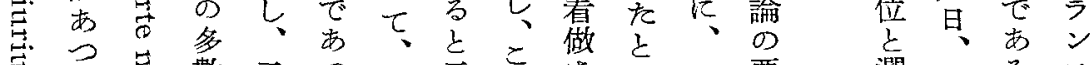

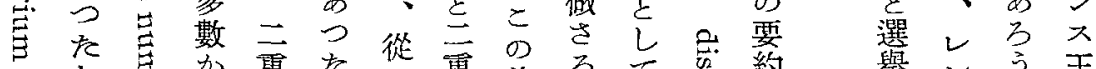

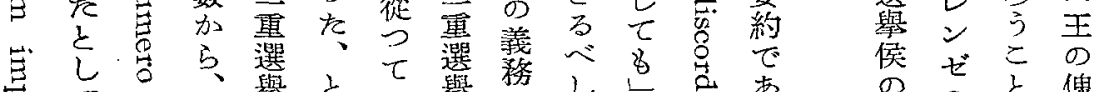

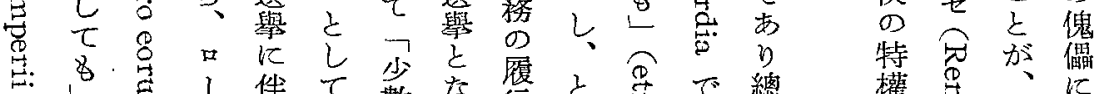

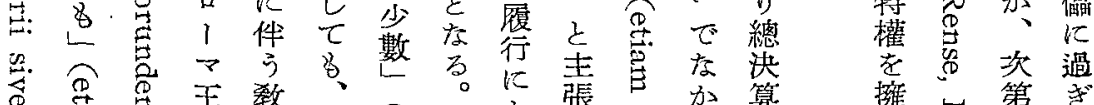

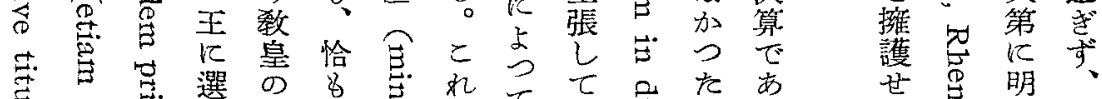

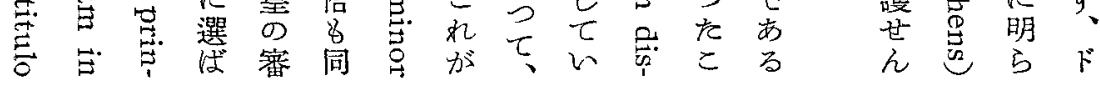




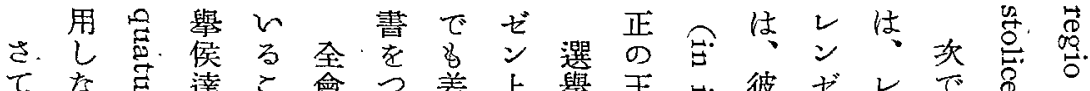

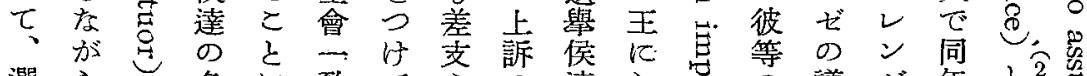

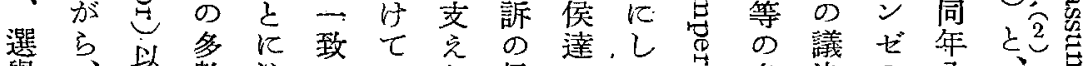

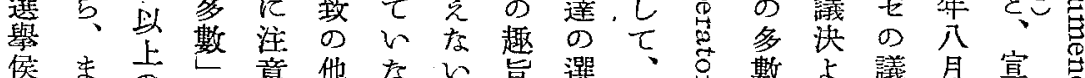

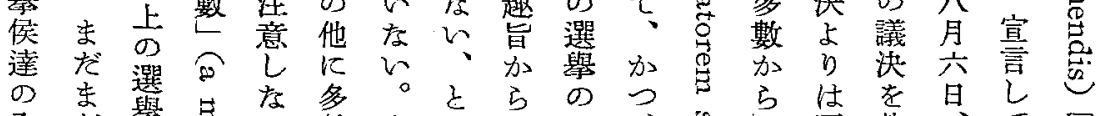

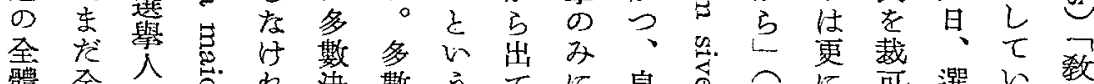

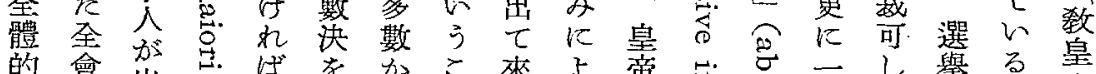

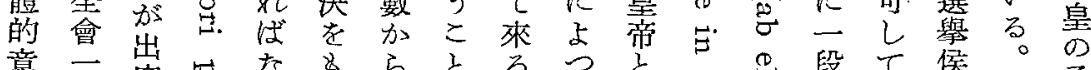

識 致 席 は

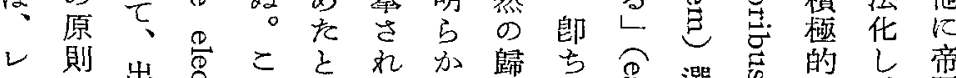

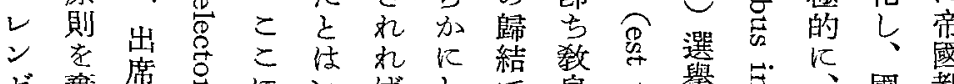

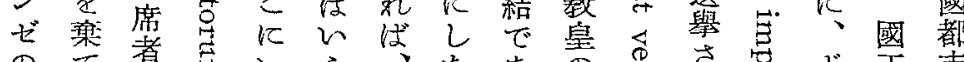

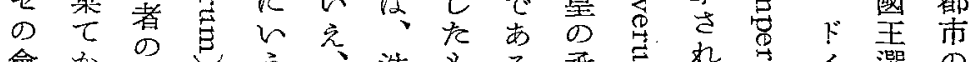

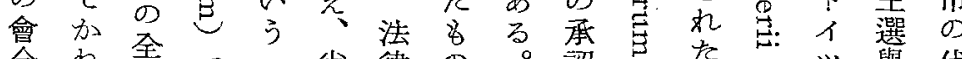

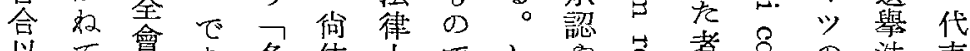

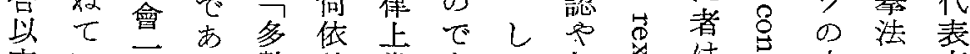

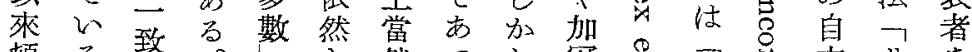

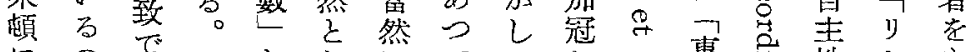
高 で 港 潠

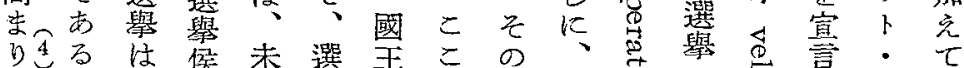

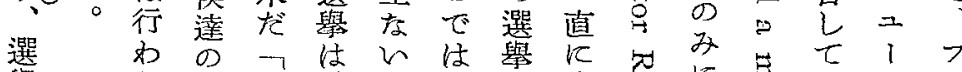

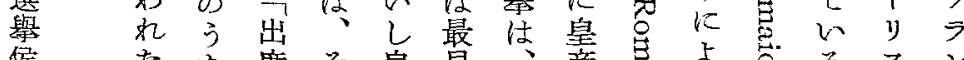
侯なち席と皇早、帝

薘机少

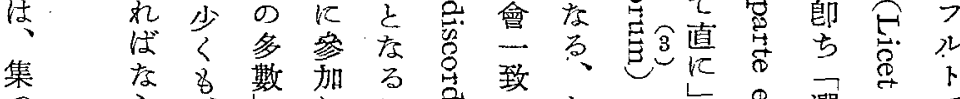
己 ら

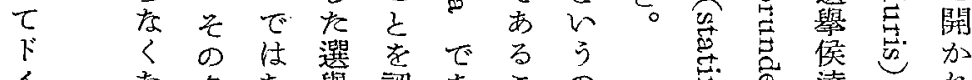

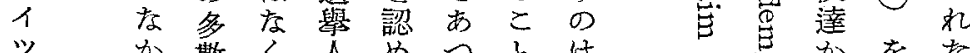

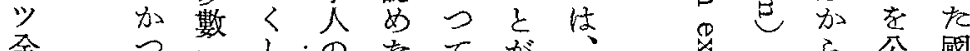
全 $\supset$ ᄂ

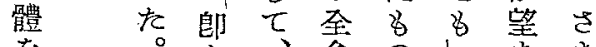

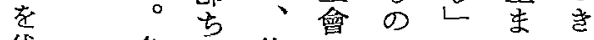

代多四依二でをしの

表嘍人然致あいいぜ

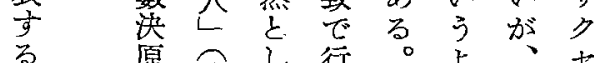
る 原

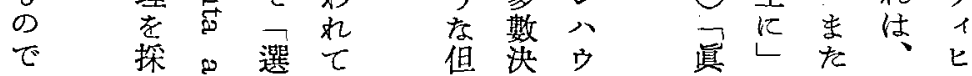
を 必 要 $\frac{2}{\frac{1}{9}}$ 


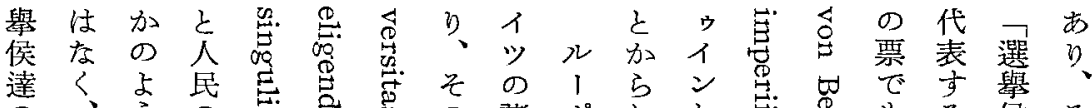

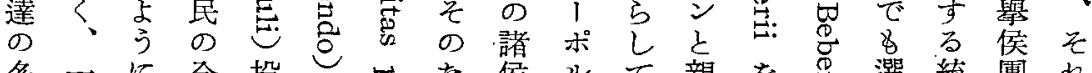

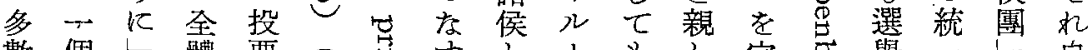

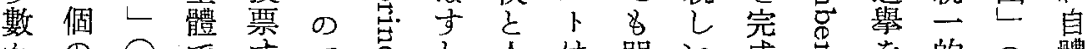

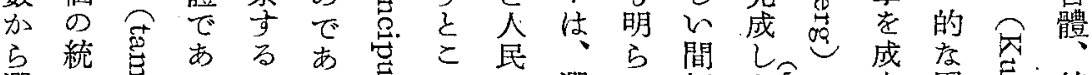
ら 統总 あ る あ 㦛 的怘当

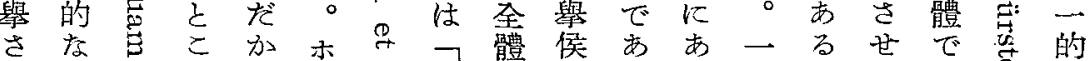

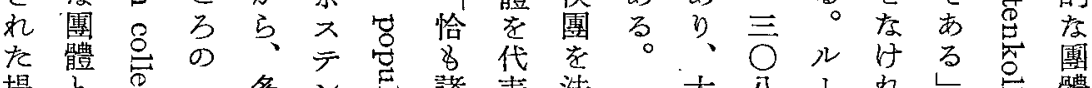

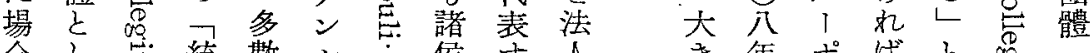

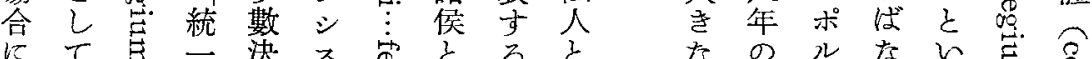

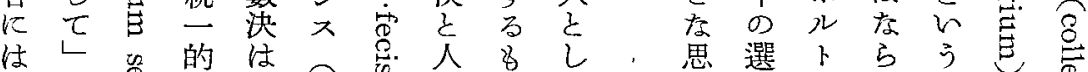

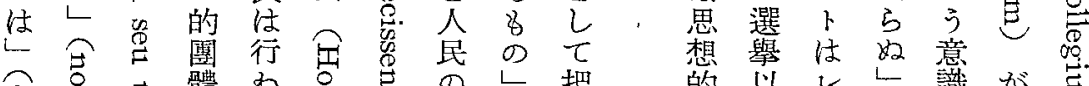

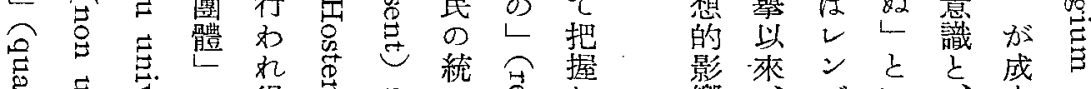

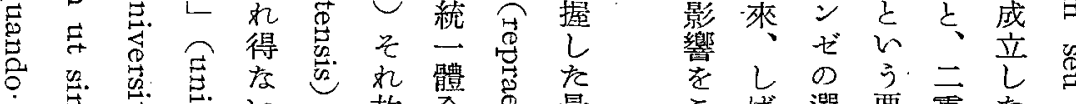

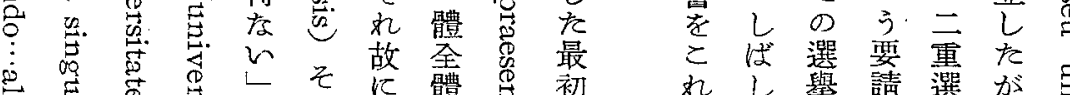

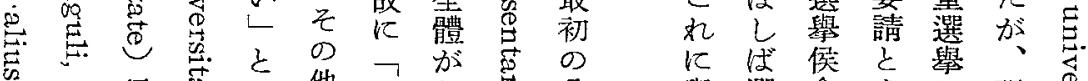

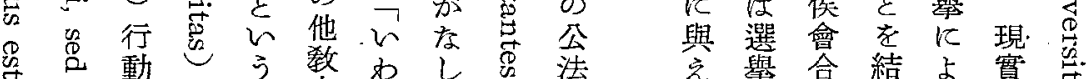
』

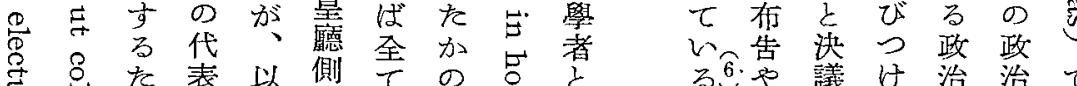

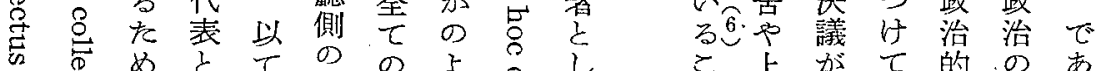

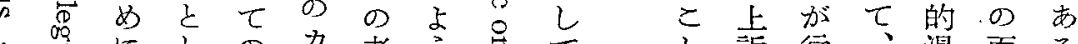

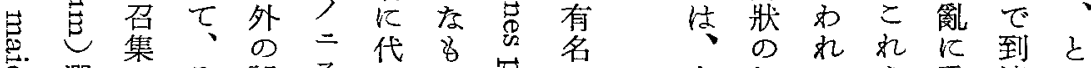

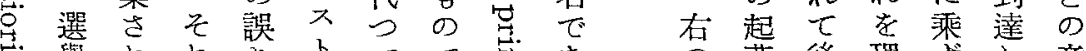

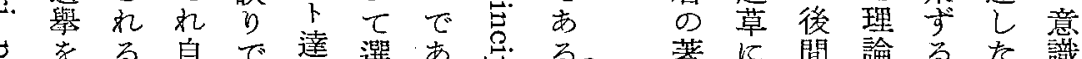

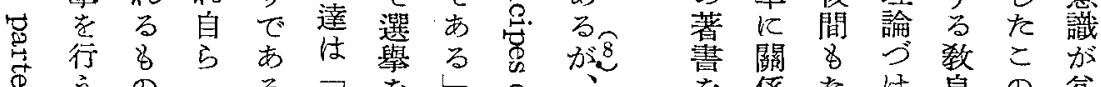
D

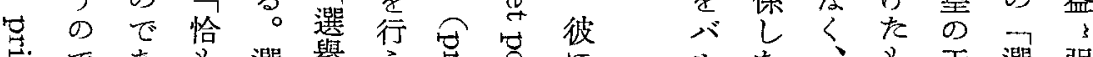
点て あ 8 選舉

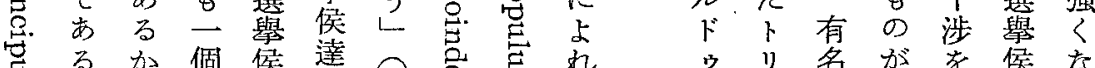
异るか個侯達合灾志机的り名がを侯な 声從

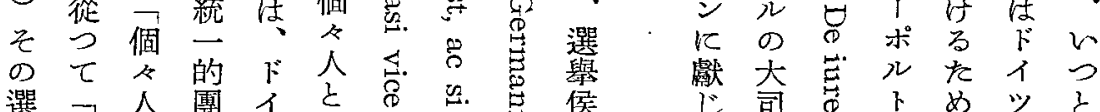

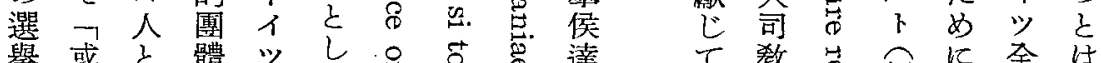
擧或と體 ツ

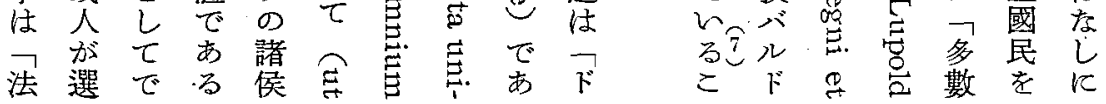


\& 打選指投で和つわよ疗問張の

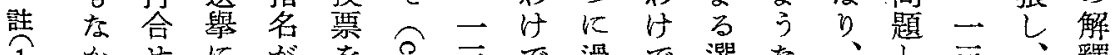

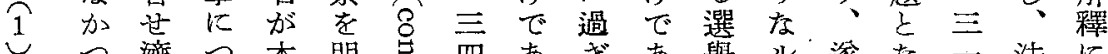

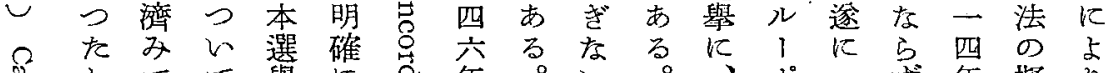

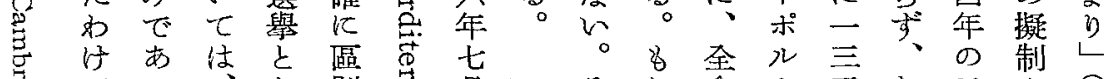

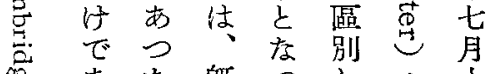

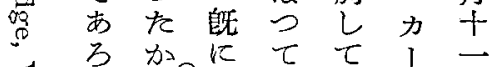

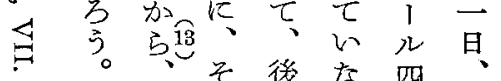
從特 搬市世四七

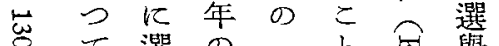

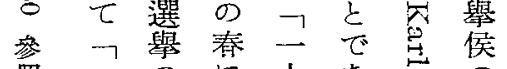

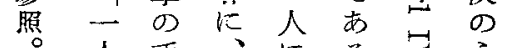

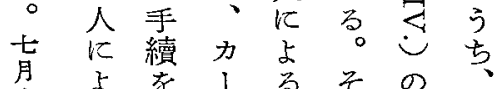

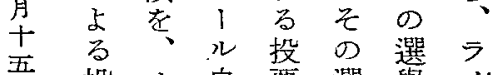
音投力自票選舉 k 票, 親 8 法 ヴ

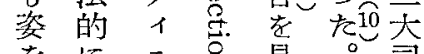
沙嚴 $三$ 灾見こ司 L格

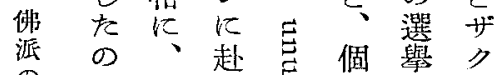
心 で行い主别に七

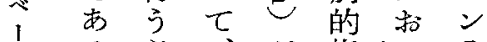
×当必加指证公 王要整消名客忘

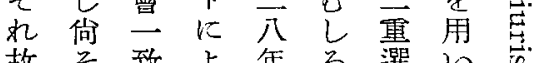
故 そ 致上年万選々岕

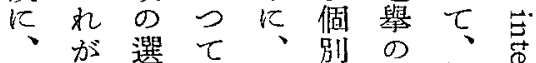
乙引舉代指的際多寻 の續で表 名にに 數岂 最きあさの行は決导

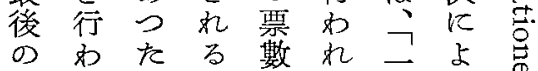

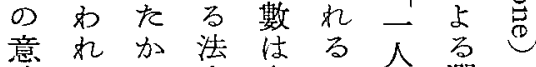

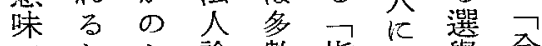
でとよ諭数指よ㦛 全 のすうをで名るに會 密机柰多可上投全致

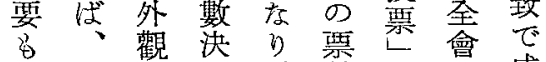
なそを原、數に合 $<$ 與理々 00 , 致立

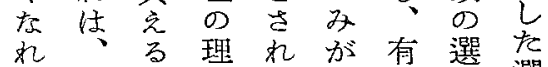

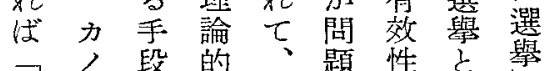
ᄀ之段的其題性它擧 人法乞硅數なっ主 に.の七付決つき法官

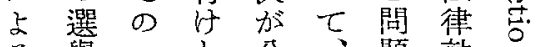
る 舉 $\neg$ 公、題効 投の一が公儿帒果五

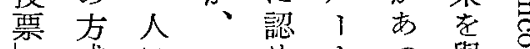

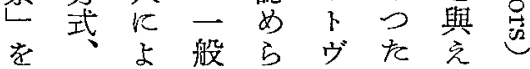

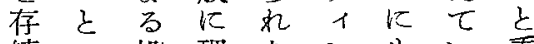
續々投理た $を \&$ 看 せ引票解のを少る做 し意死さで敉かのさ め味はれあ皇わでる

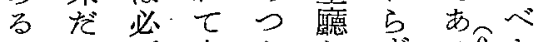

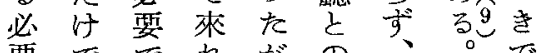
要ででれがの、ず は、蛙、間そ市 な命吾今

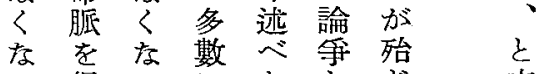
る保るにたとを゙主 
なとを 蛭

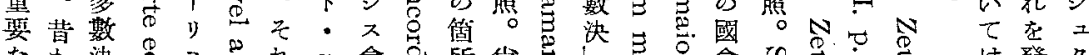
な加決总

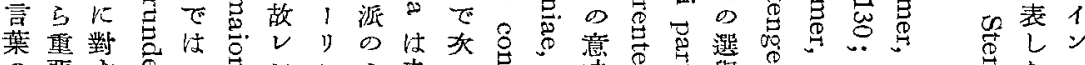

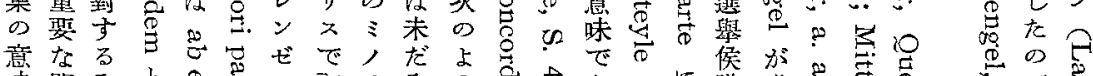

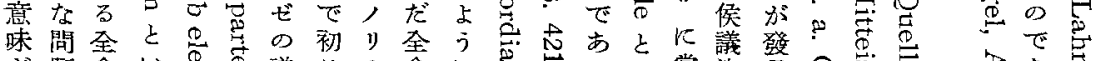

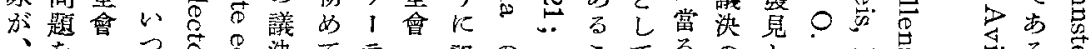

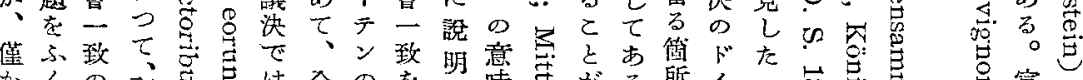

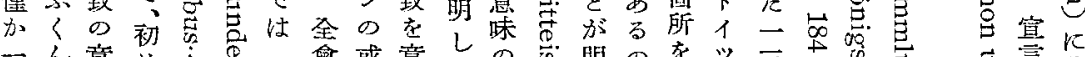

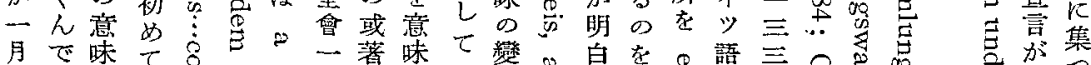

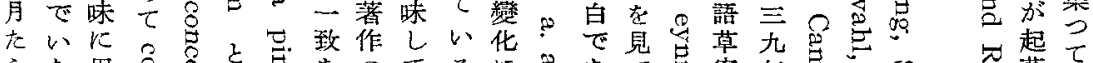

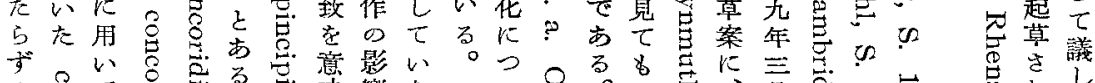

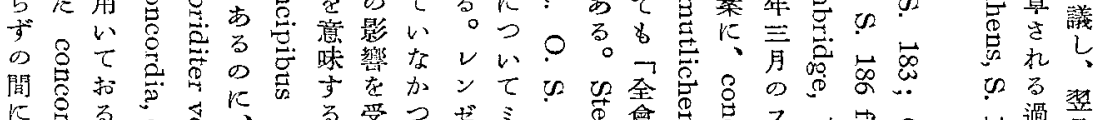
K、る 秒

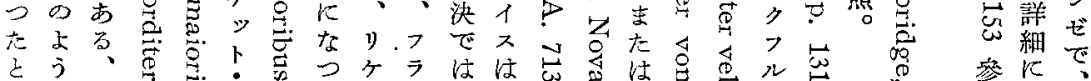

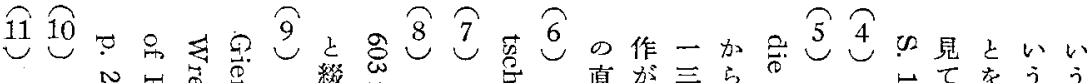

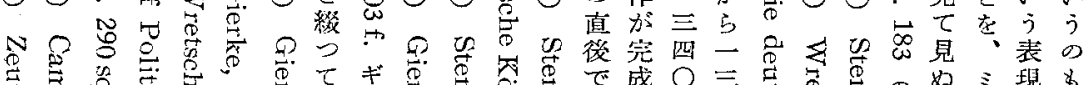

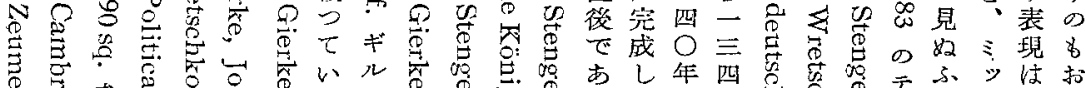

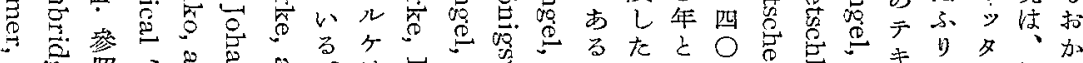

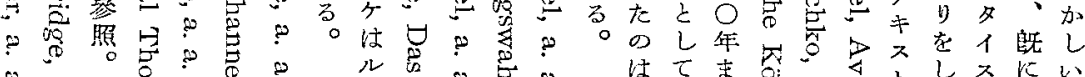

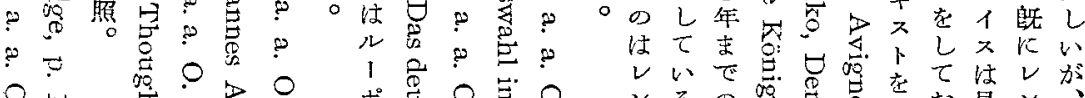

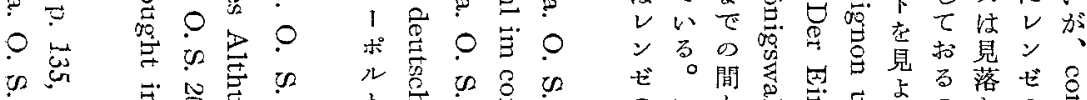

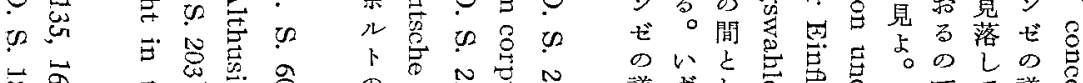

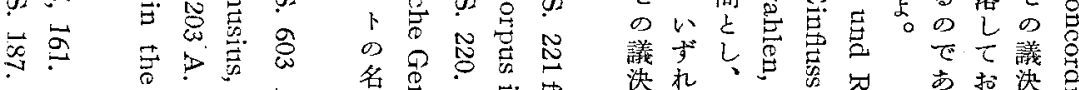

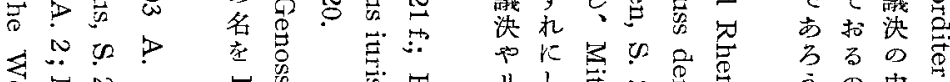

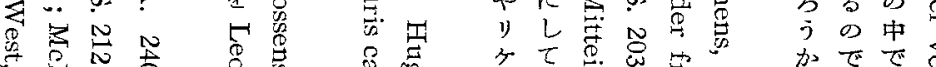

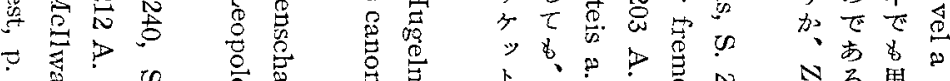

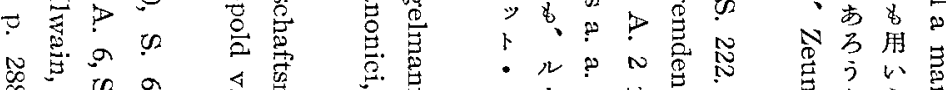

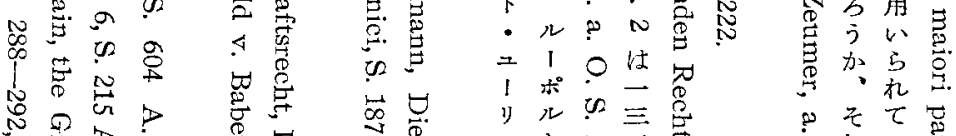

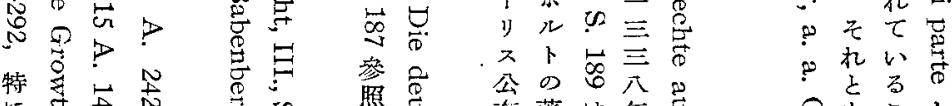

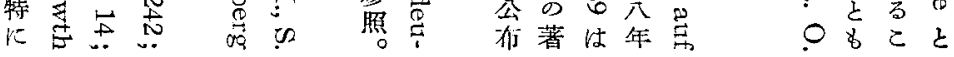


出虍三化さ書

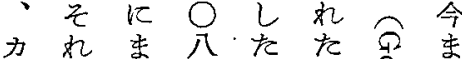
故で年多多官て 法住高 諸 印 れ 規 勅、 リて に 定畫潠七 七 從發 探文舉七 そ

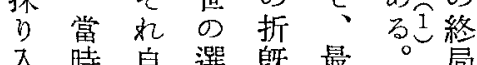
入時自潠 既最こ局 て 現を布行にれをを 行な告わ行はな

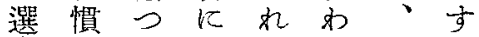
擧習て 記な视儿多 が法いるさかた の

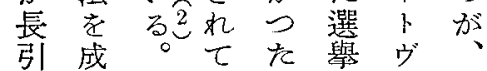
々文いーでィー 者化 る あ 门しょ人る王五

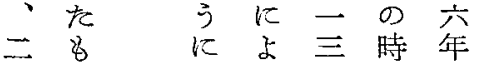
重の 当四代に 潠に览 投六に 擧過少 票 年敎力 上李李皇 1 なな儀はカ聽 ル る、式、1 $、$ 四 こ、を金ルのあ世 子 2 以印四論 $k$ がいて、勅世争よ

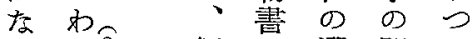
机芆 個方選間七 よる别ら擧に制 引肪的在 0 展定 に、全際開公 、少行くのさ布 萬々 わ渻方処さ 全8 水学式、就 の選、去を二た 策 擧学文 が手机、そ三こ

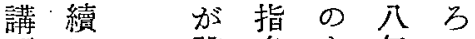
ぜに設名ま年の らつ權 が ま 如、的、立確堲

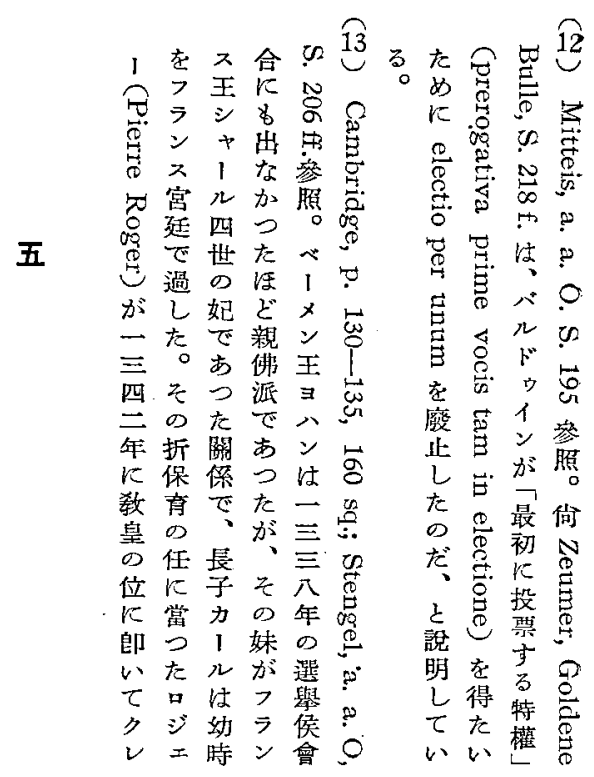

ら一ザのに招三踭县りメ 選儿七集郄、六親て敉 舉 2 狀皇交年交、皇六 のン公を廳換春あ親側世

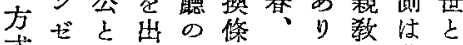
式火力さ能件力フ皇敉な な゙集 Iし侽付 I $ラ$ 派皇つ

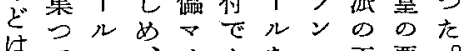
はての、イカを王泟。 初、父教义１交王壳求折 めカ心皇ツル心゙空立をし

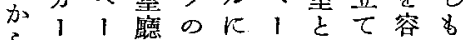

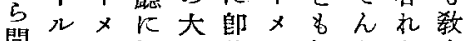
間をン買司位ン好とな皇 題主王收教承王心し心聽 でにとさを認々カてルと は選が机しの共了い、 な立二たて内的几た卜1 か立三他新諾了に。が つた四の主を光目そイと をの六二選與 1 をとヒの ので年大與亲二つでを間 であ十司のるョけ教位に ある月教たとン皇加争

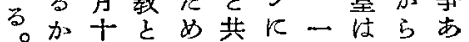




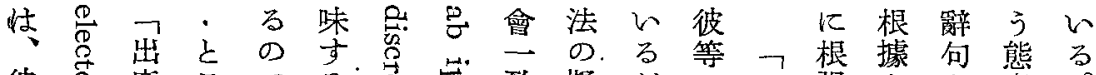

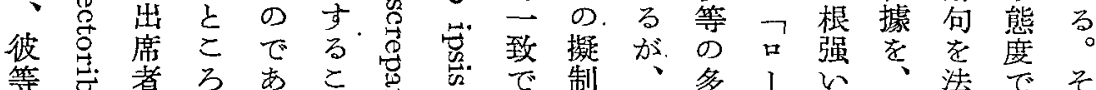

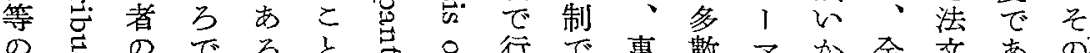

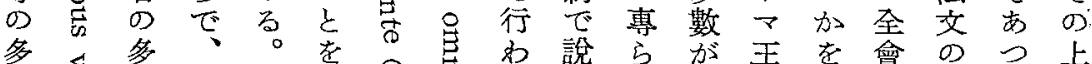

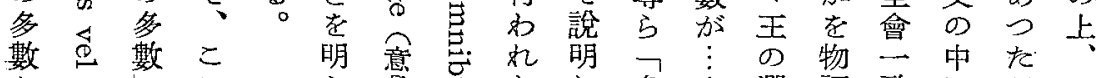

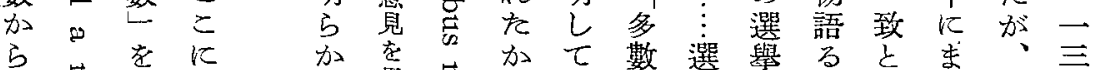

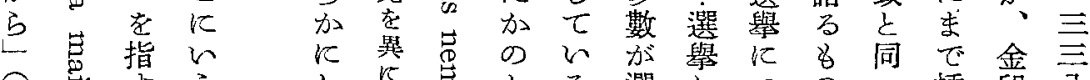

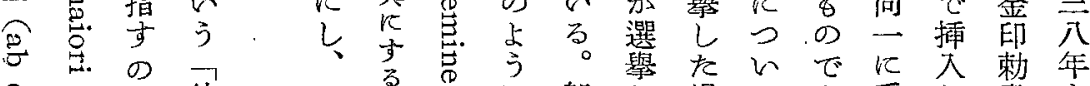

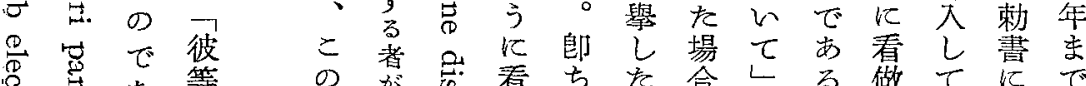

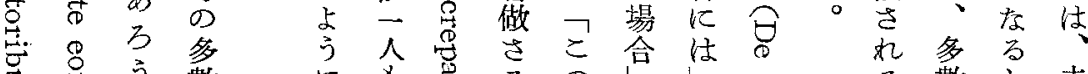

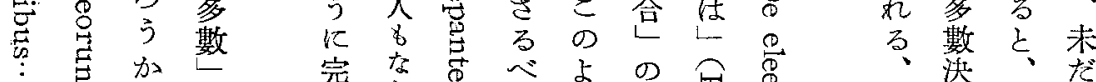

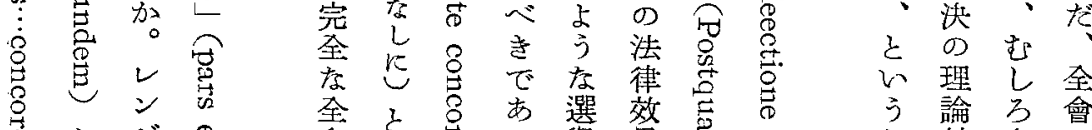

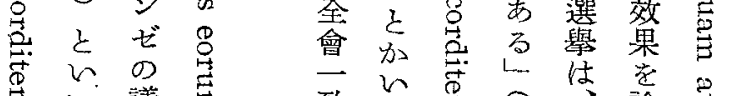

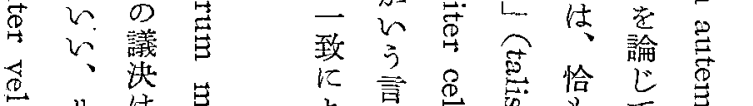

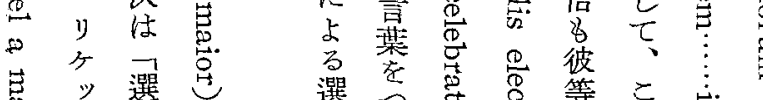

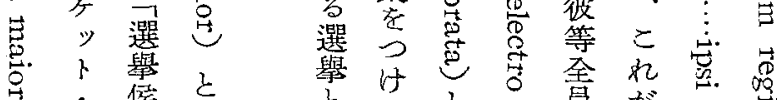

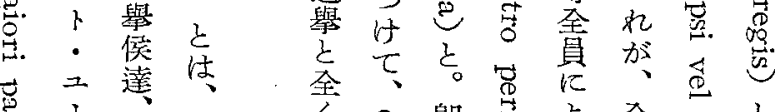

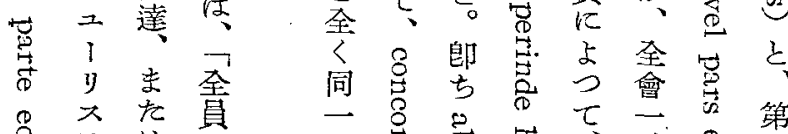

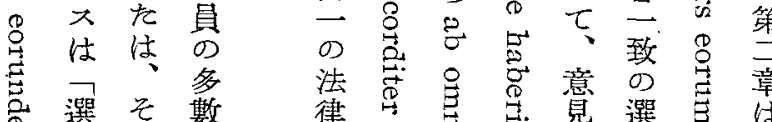

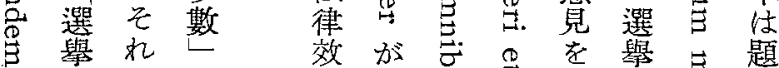

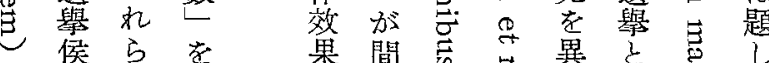
と達の指 的多主 $\supset$ 數 の

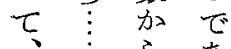

全占方

ず會 ○う

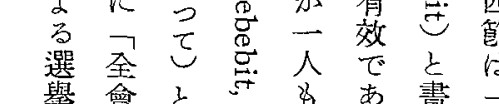

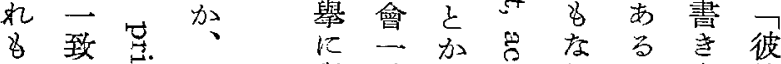

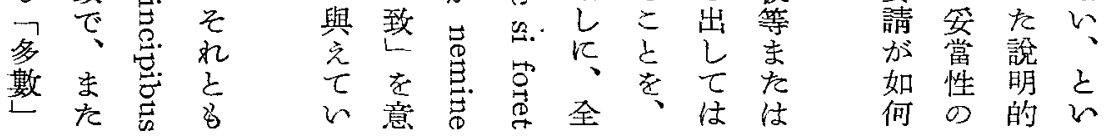




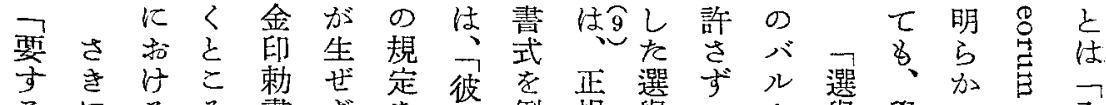
るにるる書ざを 等例規藇へト舉學で引全

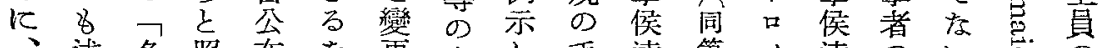
述多照布老更多し手達第入達合W 三心 數 合 後 得し 數 た續 ま

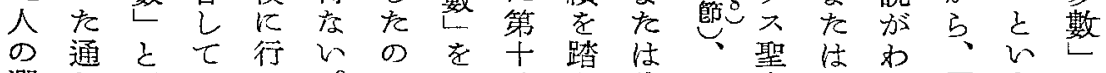

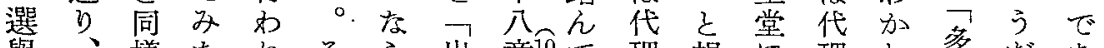

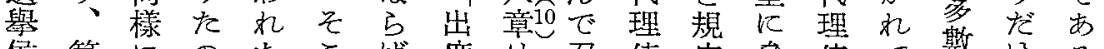
侯第にのた代席は名使定參使て数ける

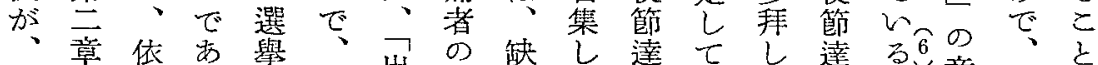
饰住然 る の間國し 㤎祭章者 數 者

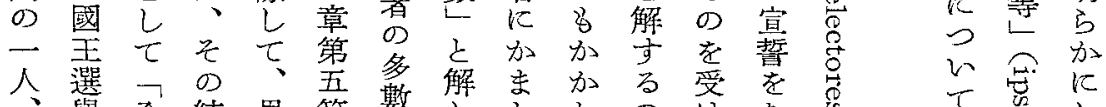

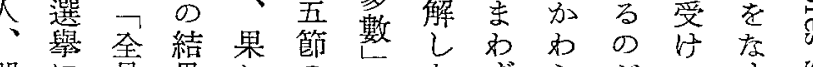
郎に 員果 乞

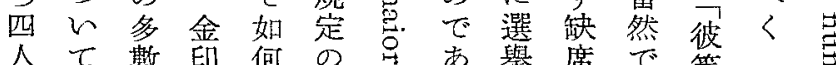
人て 數 印 何の标古譽席で等

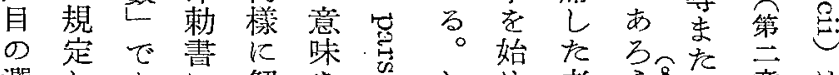

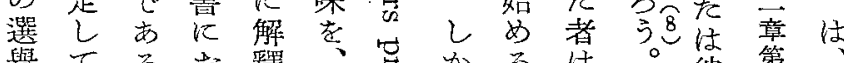

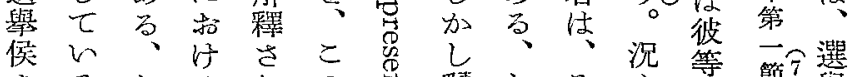
をる 子 る 礼 の

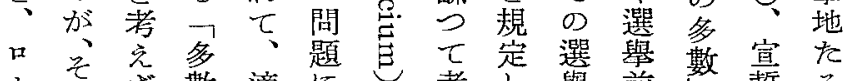

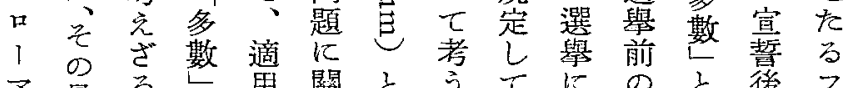
王最る に後を得如热明るる

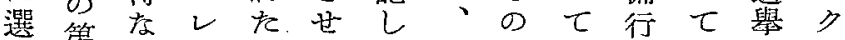

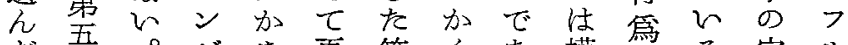

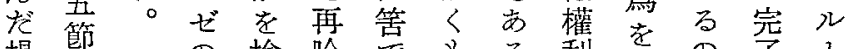

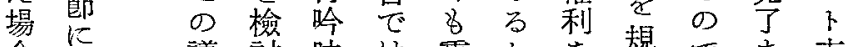

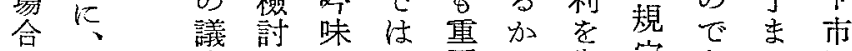

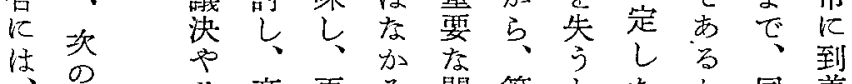

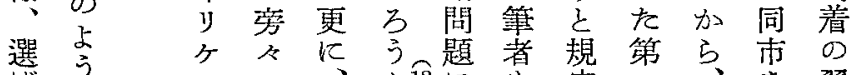
㟟方

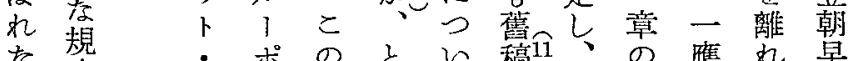

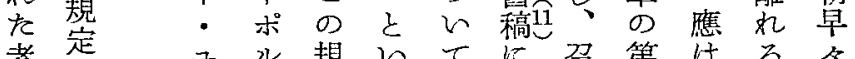

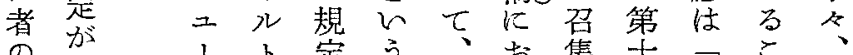

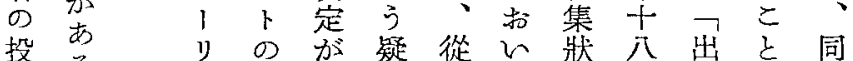

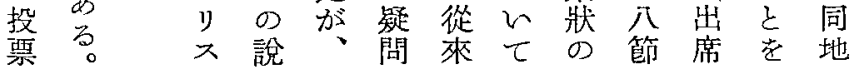

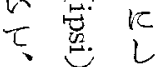
賞 註 果学 w金 $\tau \rightarrow$ En 全賴 解買墨 䆁指流 क 單 拿 8 肪の 应加彼 证、等 つをま を礼灰 わ之は け 多彼 で ᄀ等 站出 紊著 多 峙を

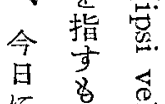
亿 \& 市少岕 


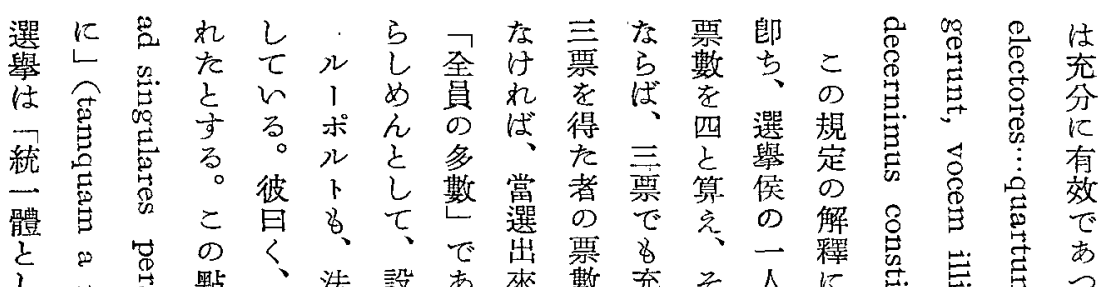

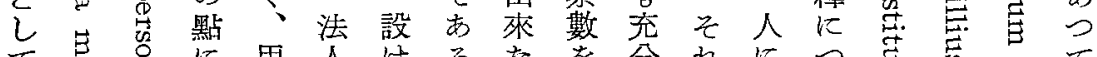

て

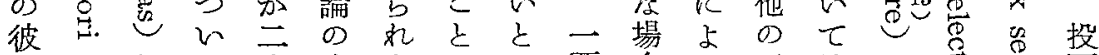

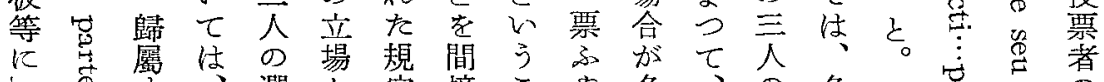

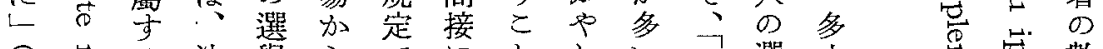

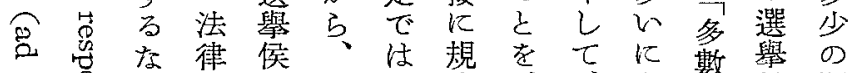

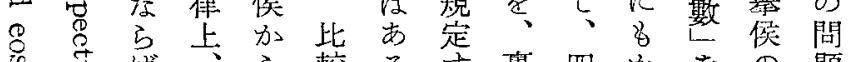

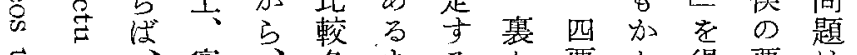

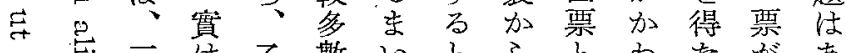

ڤ

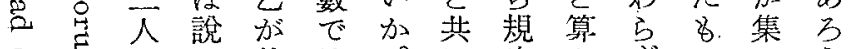

8 吉分仿他

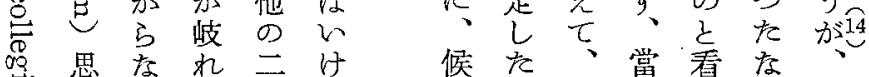

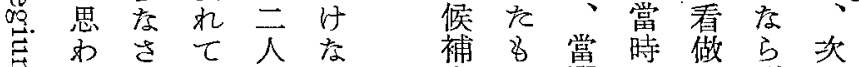

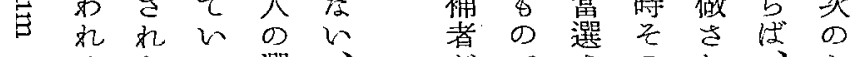

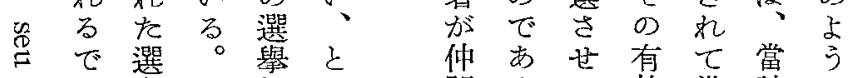

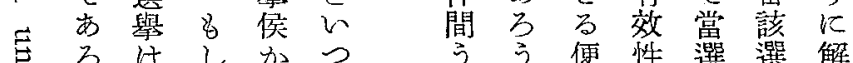

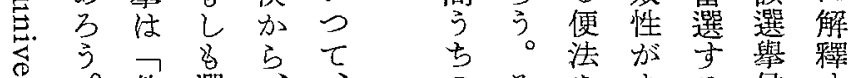

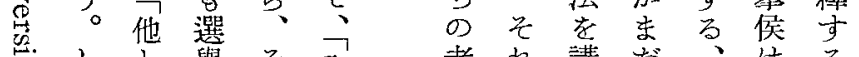

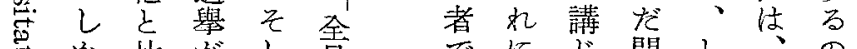

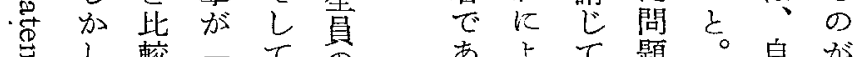

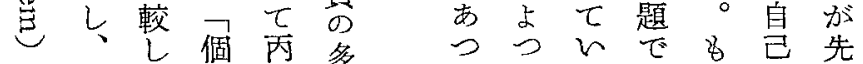

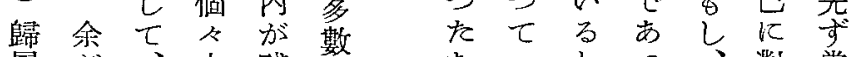

屬㤎人残數店々とつ、對當

专正多りで方彼いた出しつ

万し 數し の な

子、加

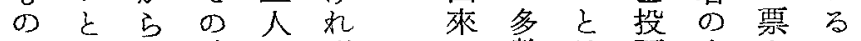

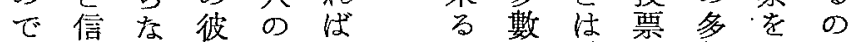

あ孛さ等選な放投で

るる的に藇ら汓々少許でしは

・說たし侯ぬ當はくしょてあ

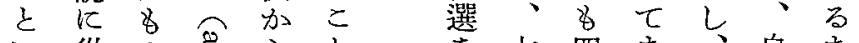

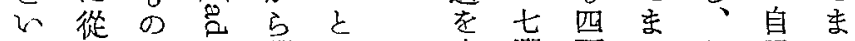

引つ の 葓を容選票でを己い

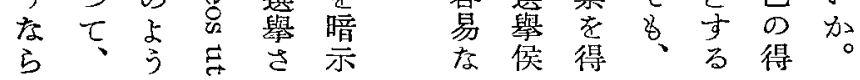

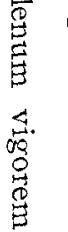

數

增

寻总. 數

号成

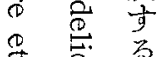

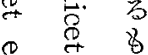

๑.

魚蒙定

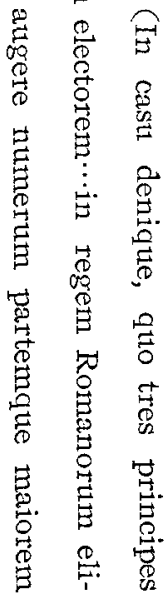




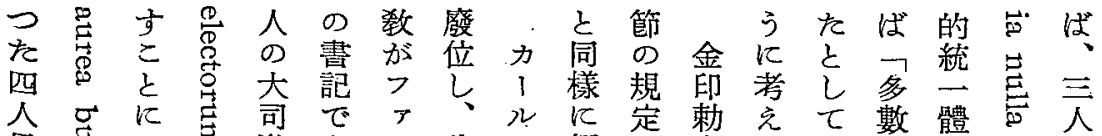

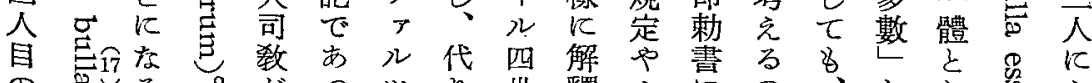

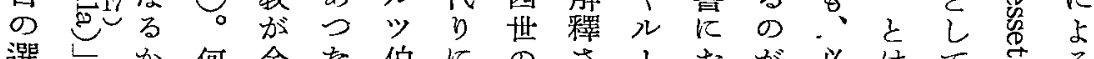

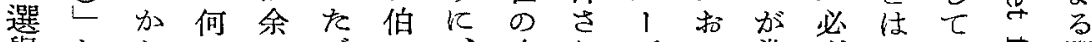

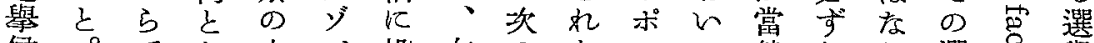

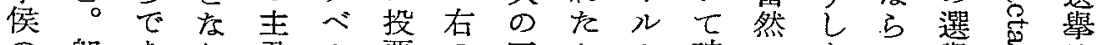

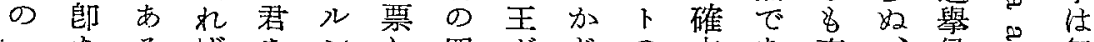

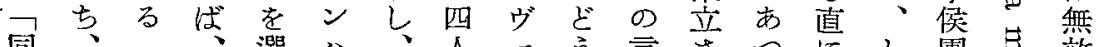
同、葓 八、人

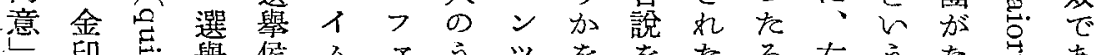

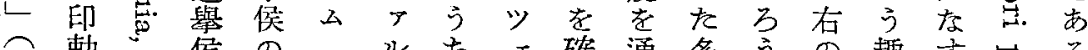
ஓ整書

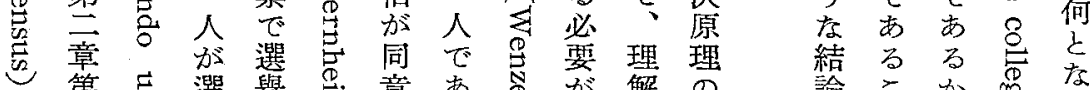

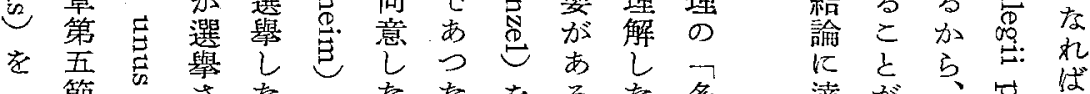
二節

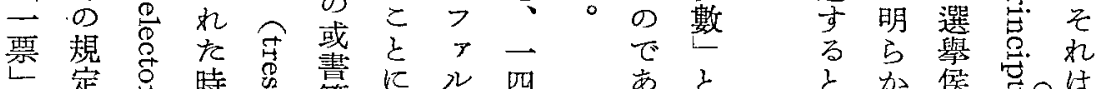

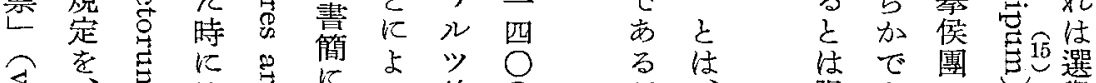

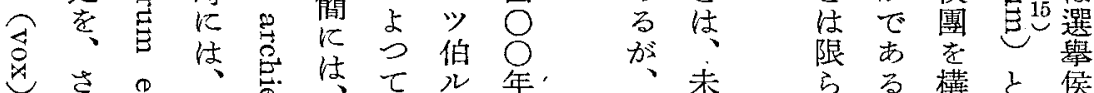

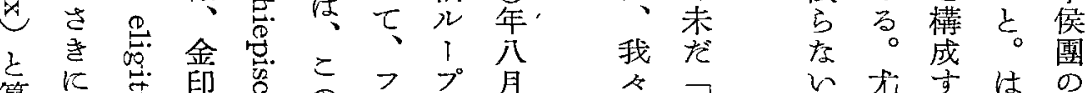

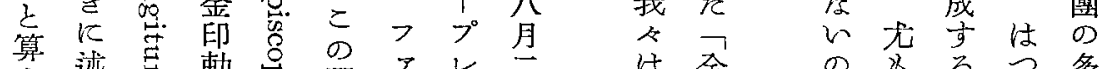

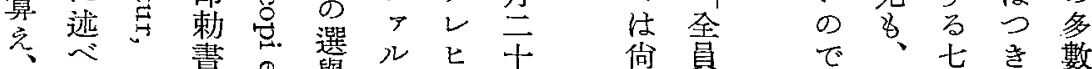

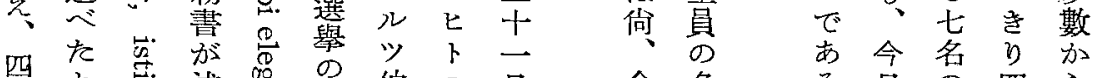

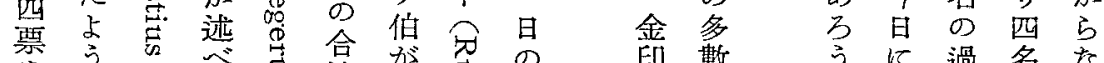

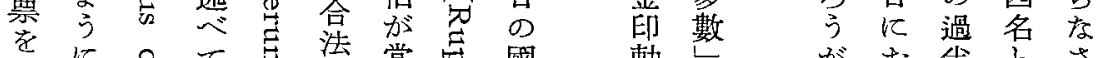

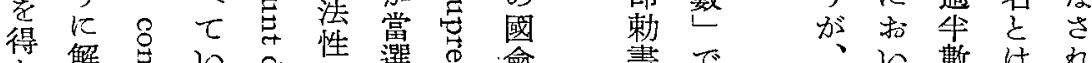

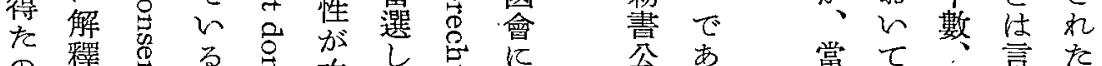

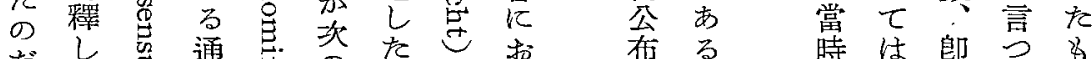

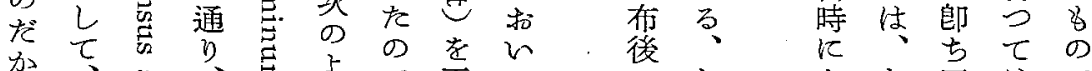

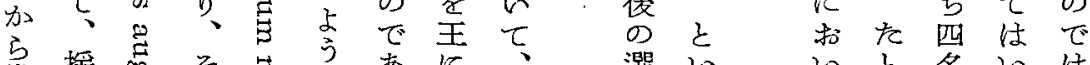

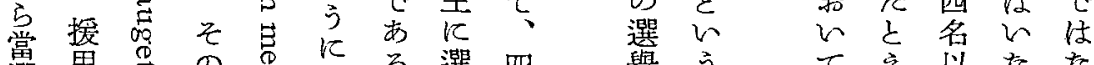

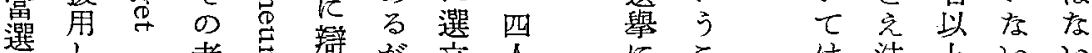

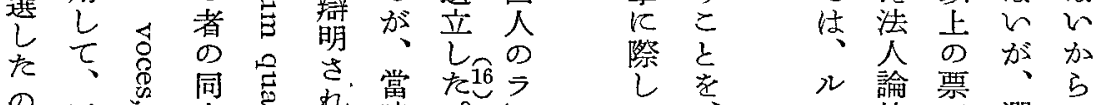

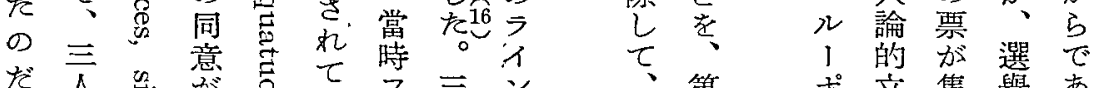
だ 人

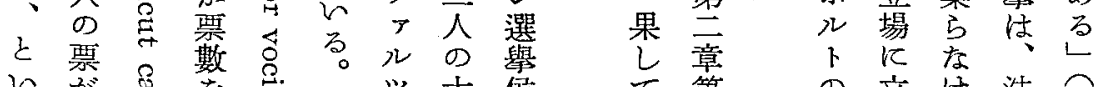

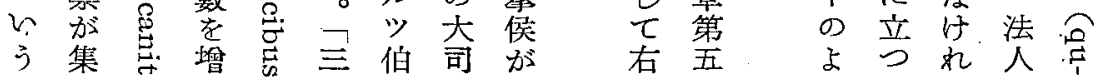


金印栜書における多數決原理の成立

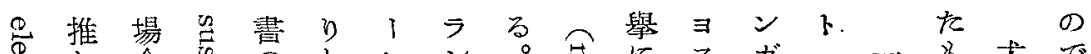

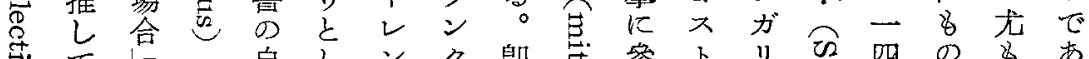

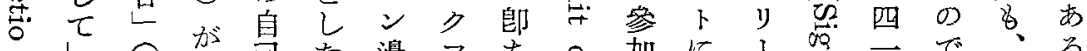
莙公含岳投范境 ル

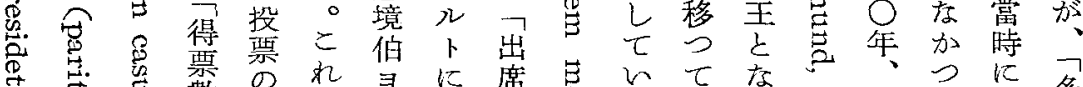

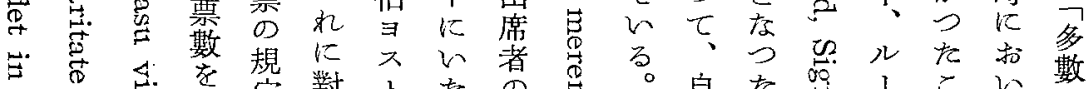

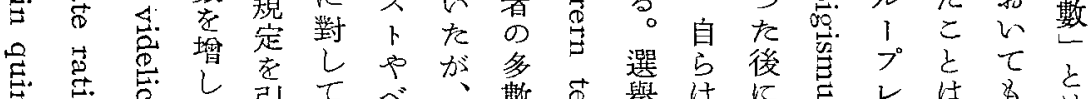

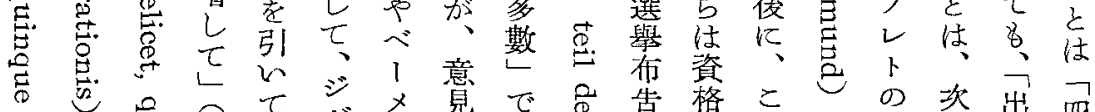
菅无

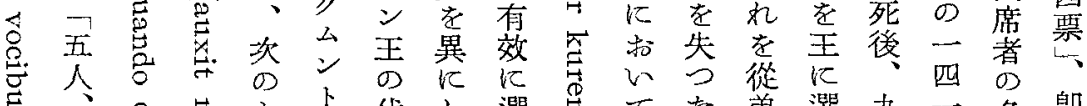
蒠

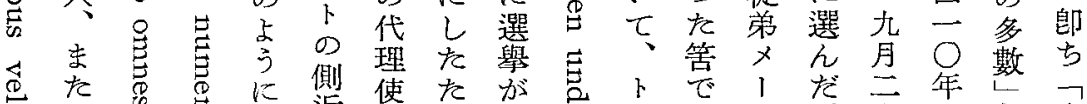
它は心寻述近者 節め, 行 そ.

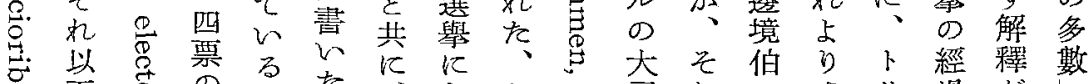
节罂官

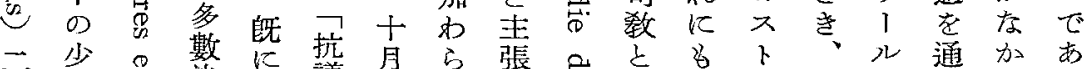
人 數 䜤

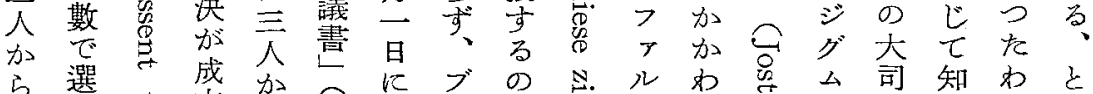
瀷 擧 导立 舉 が覃 す

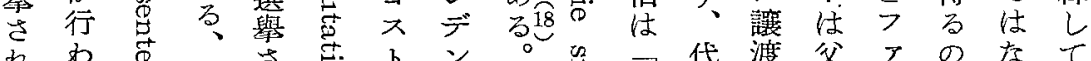

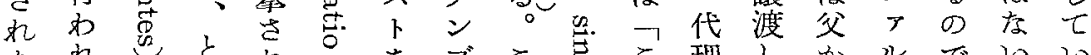

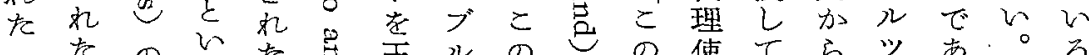

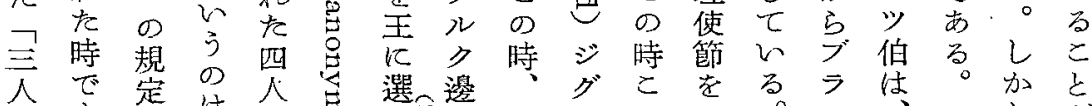

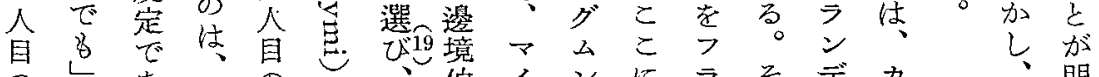
のレあーの

同 Љ る 選選つ

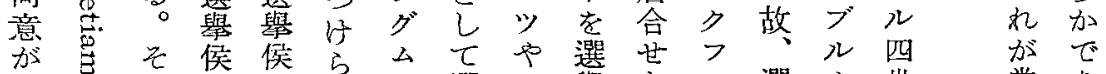

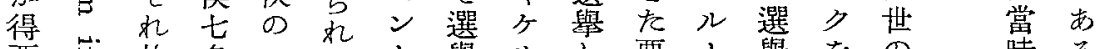

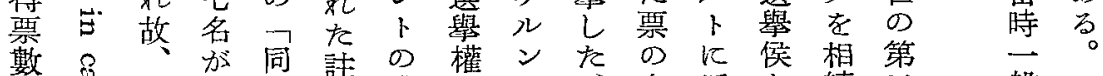
數

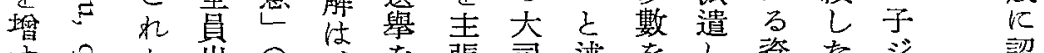

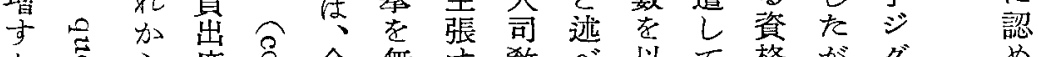

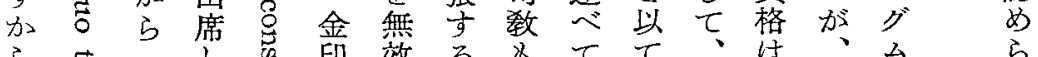

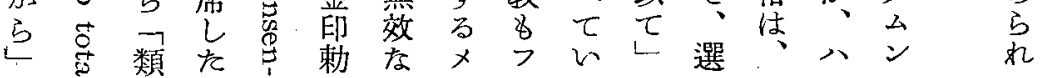




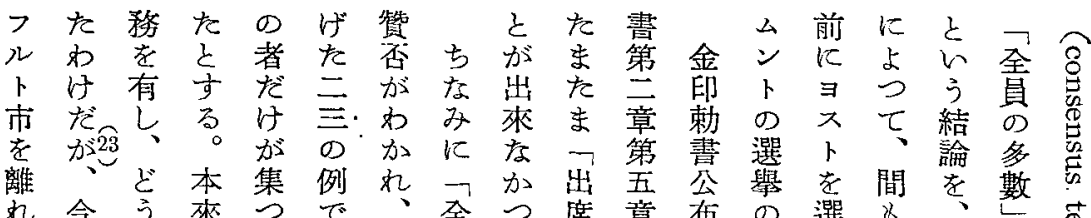

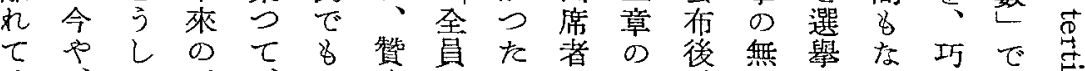

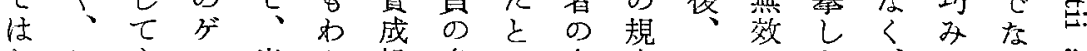
なこ名儿出か投多い多定三驾を、にけ远 られ同 $\checkmark$ 席る票 數う數に包宣選選引れ的

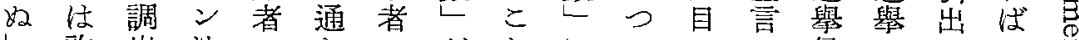

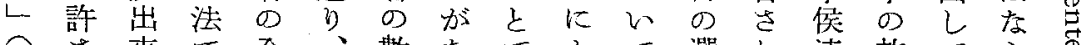

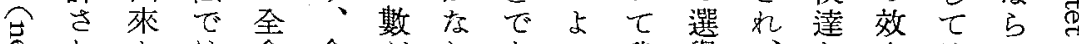

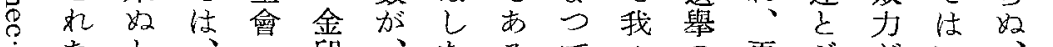

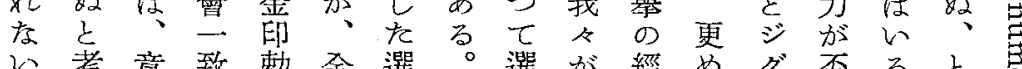

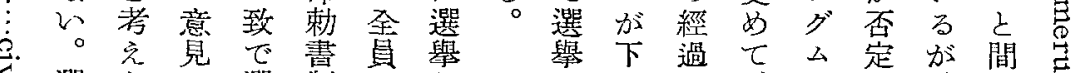

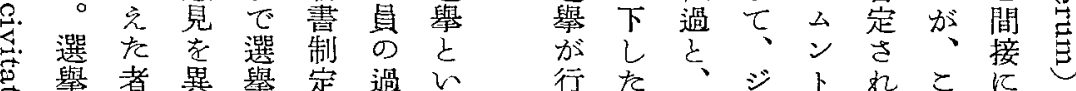

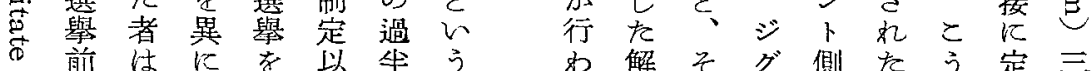

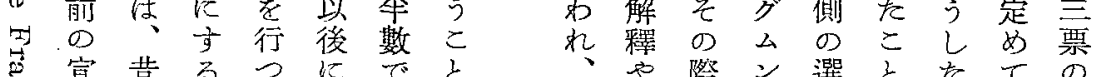
宣昔るつ汇で

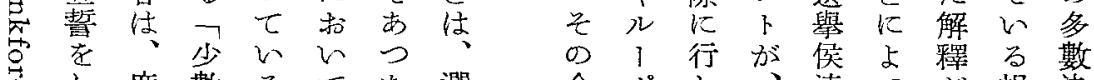
こし 席數るてて選合术わ、達つが規決

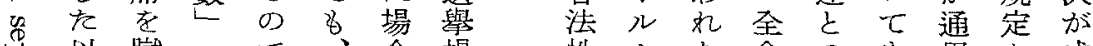

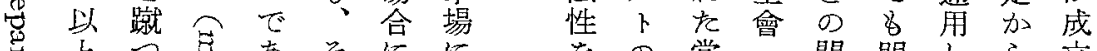
至至导

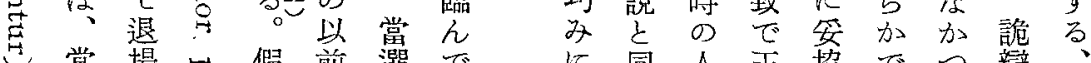

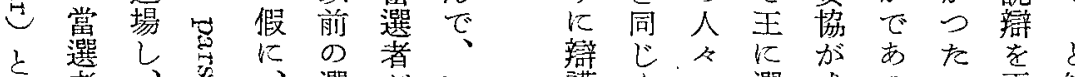
規者、边、選が心護くの選成るこ羙結 定唯そは不舉決よ方諭ば立。とし 論

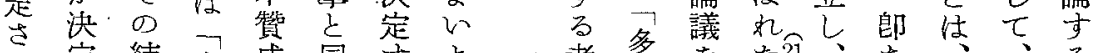

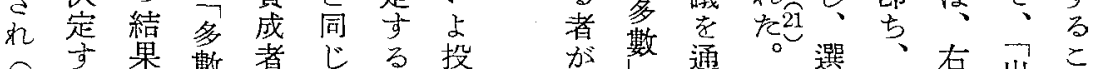

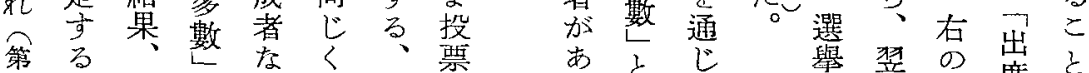

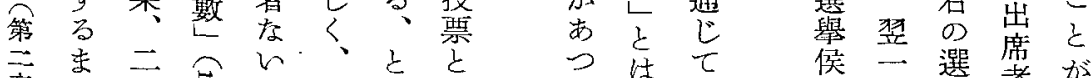

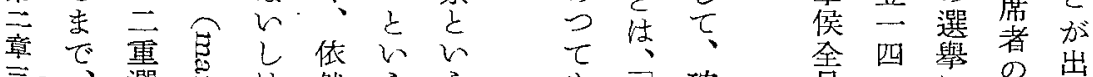

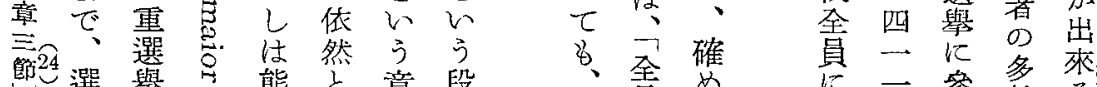

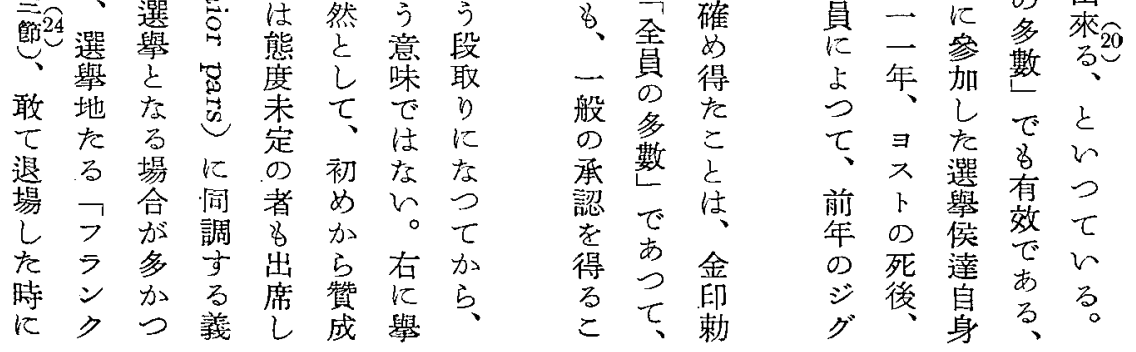




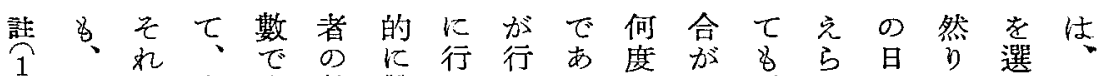
1 結 故 牟 決 數 贊 わ

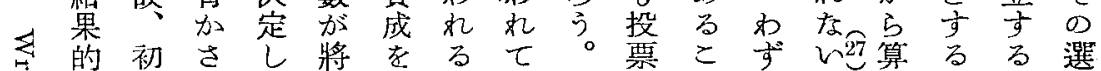

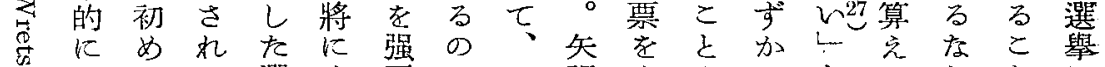

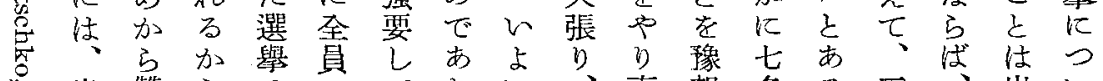
$\forall$ 出贊 $ら$ 学 席成 結過ま香昔与しでの十第來て 泀舍 者

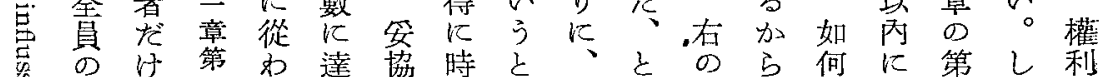

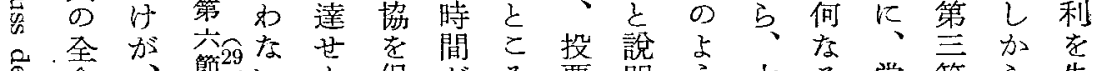

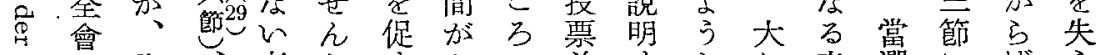

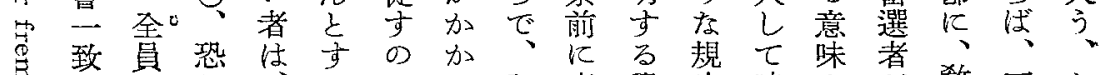

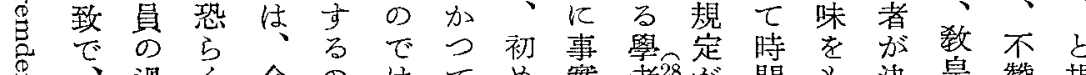

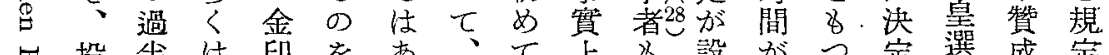

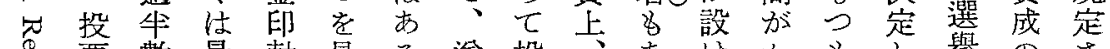

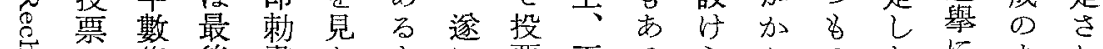

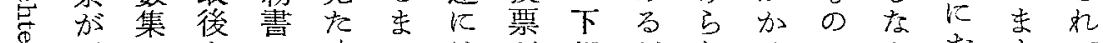

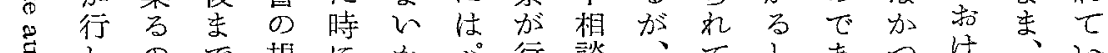

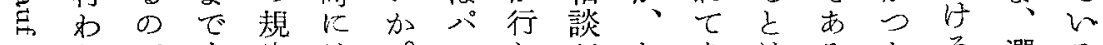

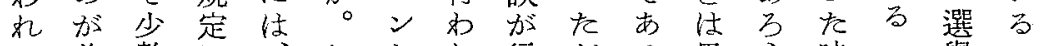

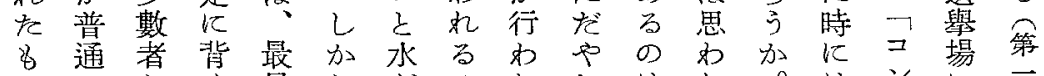

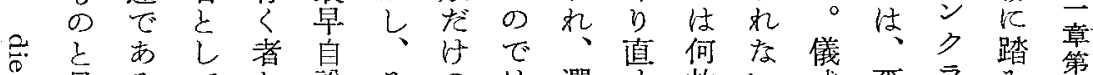

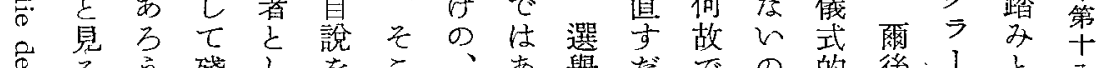
㝵方

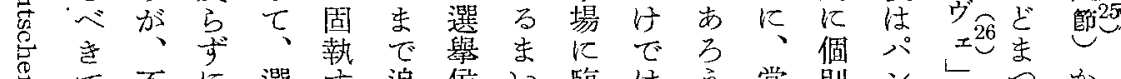

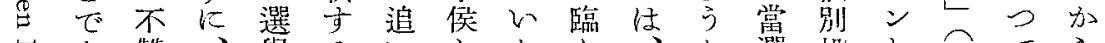
灾 あ 贊 、 舉

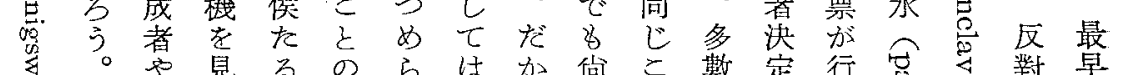

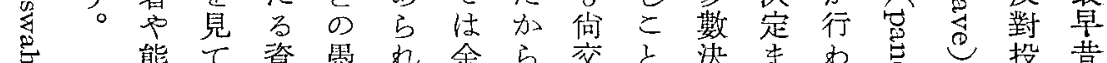

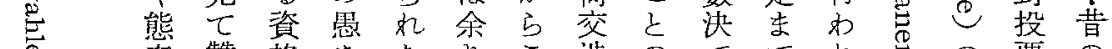

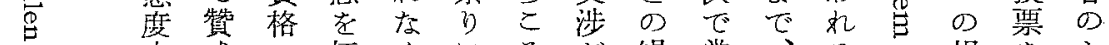

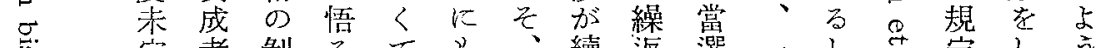

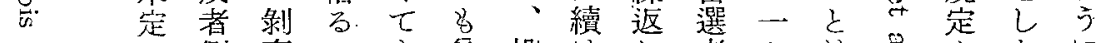

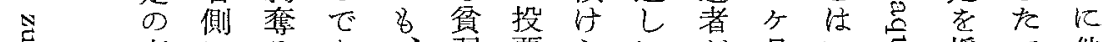

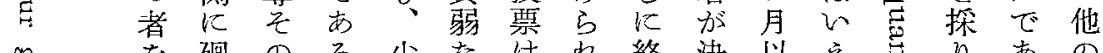

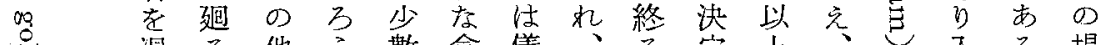

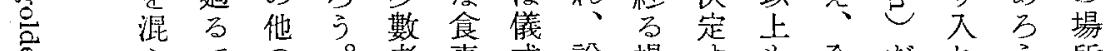

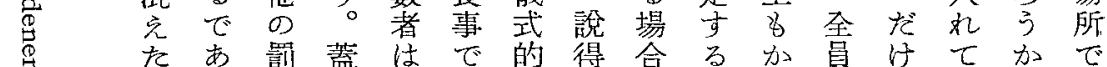
索 場 莺 合 


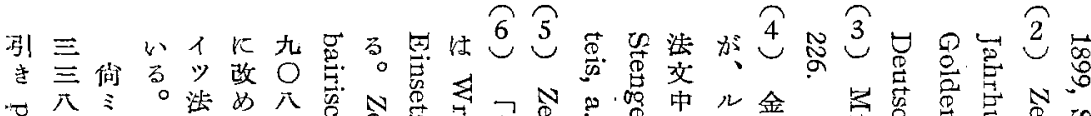

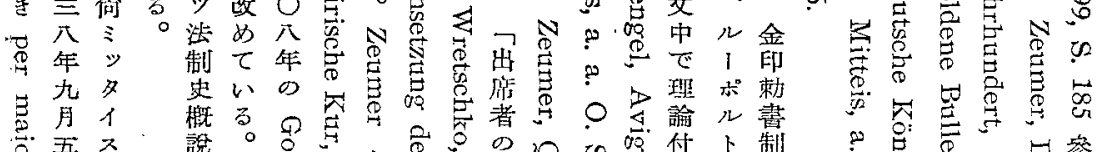

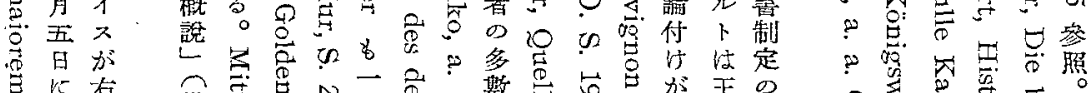

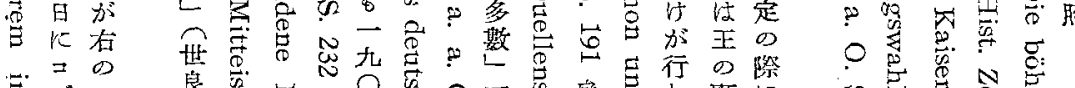

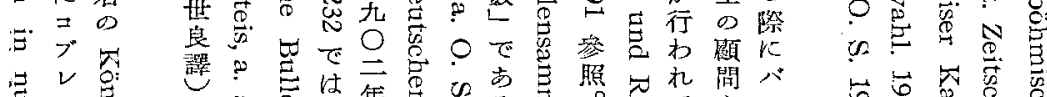

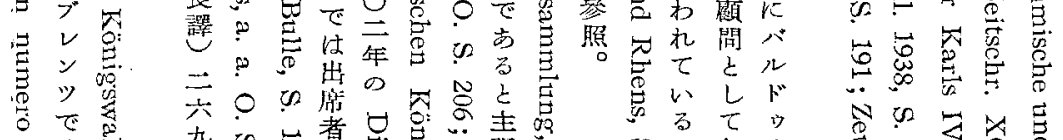

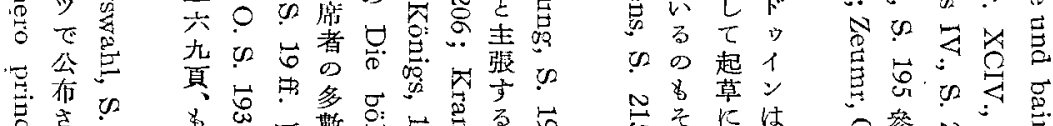

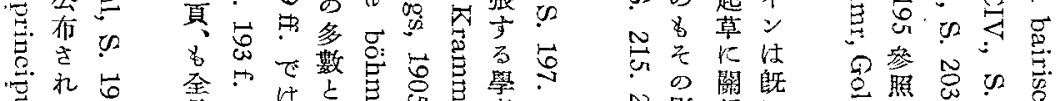

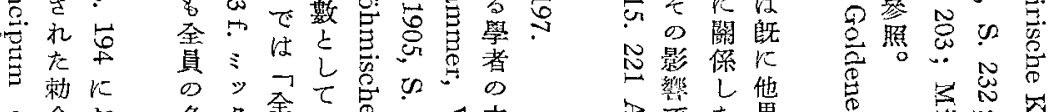

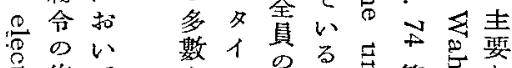

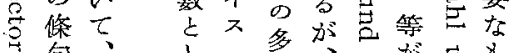

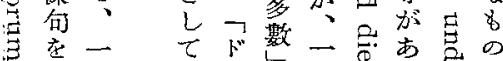
$p$ だ た 界 a

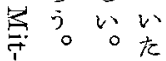

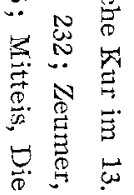

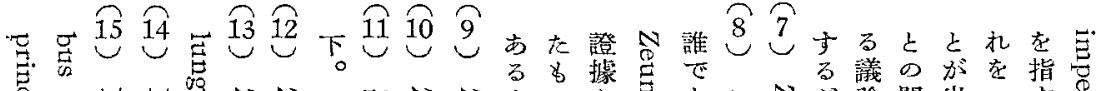

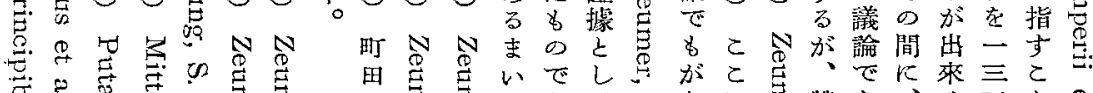

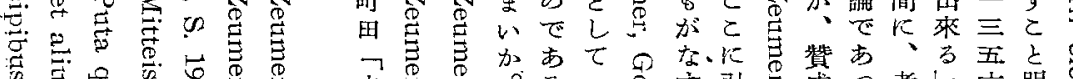

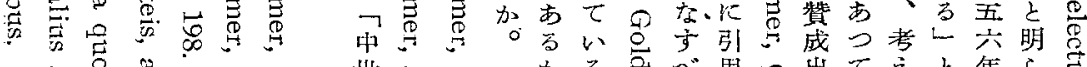

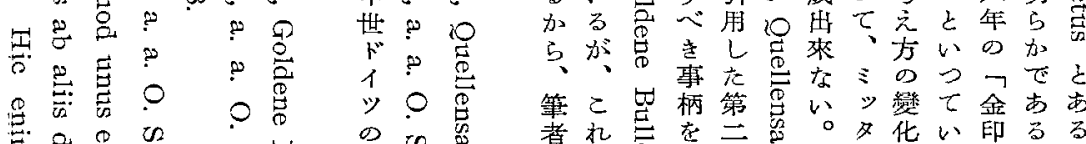

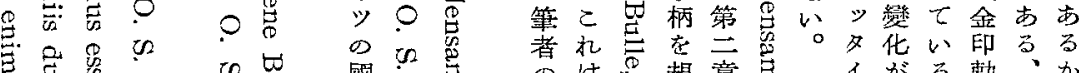

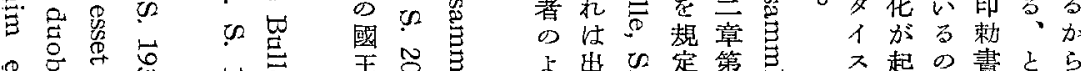

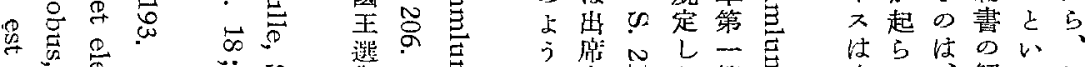

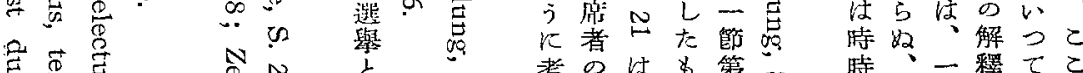

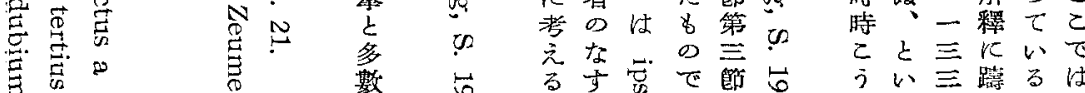

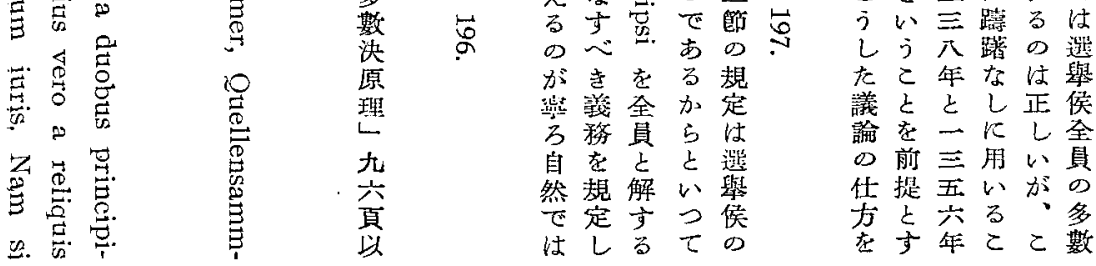



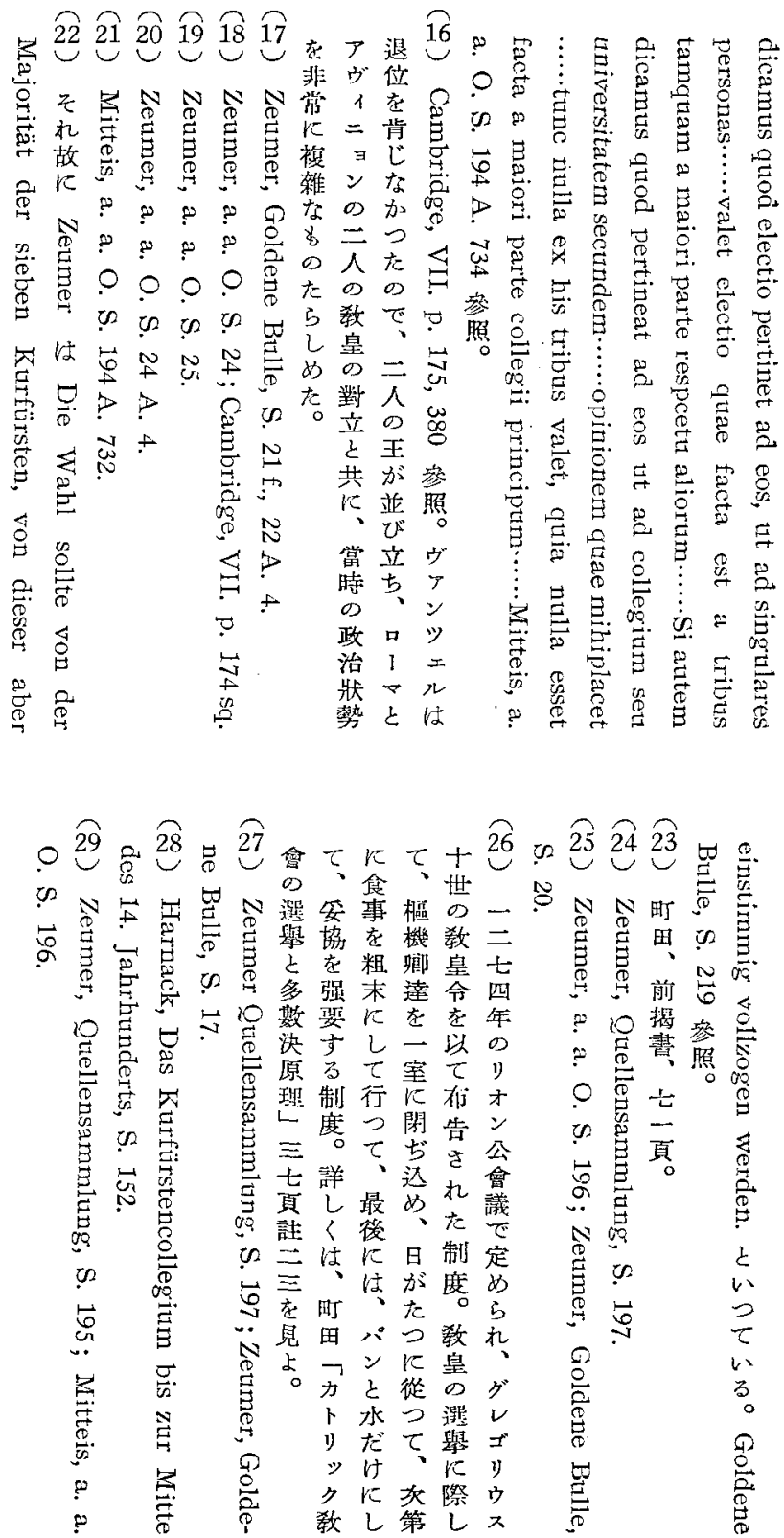


\title{
The Establishment of the Majority-rule Principle in the Golden Bull
}

\author{
By Sanehide Machida
}

Majority-rule was established as a principle, when the legal effect of the Romanic majority vote came to be regarded as equivalent to the Germanic unanimity. The procedure that a majority vote shall constitute a valid election was introduced, for the first time, in connection with the election of the king, in the Appeal of Sachsenhausen of 1324 A. D. The same principle was given official recognition in the Declaration of Rense and the ordinance Licet iuris, both of 1338 . But the election by majority vote was accepted as valid, on the basis of fictional interpretation that such an election could be deemed as unanimous. Before such a practice came to be introduced, the appearance of unanimous election, even when the Electors failed to reach unanimity, was simulated by "electio per unum", in which one of the Electors pronounced the result of the voting on behalf of all the Electors. This procedure had come to be regarded as superfluous, when the idea of corporate person gained general recognition through Lupold's corporation theory. The electio per unum was done away with in the election of Charles IV in 1346. Instead, individual votes were taken and such voting was now held valid as an empowering act. This election procedure was legally set forth in the Golden Bu1l of 1356 . In this Bull, however, a majority meant " the majority of all Electors" and not "the majorty of Electors present in the voting". The number of Electors was seven and, therefore, the participation in the voting by, and the unanimity of, four or more was necessary for a legally effective act. This fact indicates how stubbornly the idea of Germanic unanimous vote persisted in Germany. 